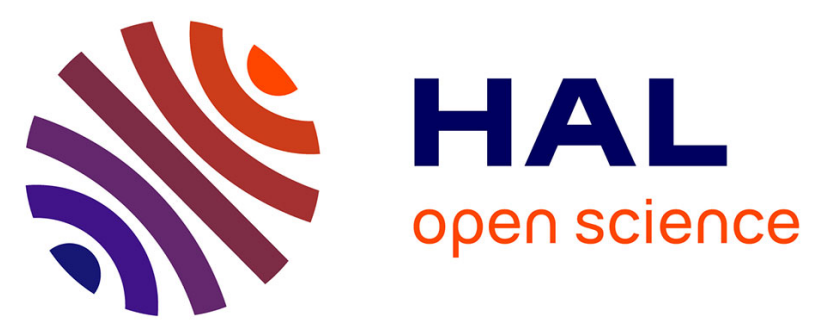

\title{
'Becoming a species by becoming a pest' or how two maize pests of the genus Ostrinia possibly evolved through parallel ecological speciation events
}

Denis Bourguet, Sergine Ponsard, Rejane Streiff, Serge Meusnier, Philippe Audiot, Jing Li, Zhen-Ying Wang

\section{To cite this version:}

Denis Bourguet, Sergine Ponsard, Rejane Streiff, Serge Meusnier, Philippe Audiot, et al.. 'Becoming a species by becoming a pest' or how two maize pests of the genus Ostrinia possibly evolved through parallel ecological speciation events. Molecular Ecology, 2014, 23 (2), pp.325-342. 10.1111/mec.12608 . hal-01837253

\section{HAL Id: hal-01837253 https://hal.science/hal-01837253}

Submitted on 12 Aug 2020

HAL is a multi-disciplinary open access archive for the deposit and dissemination of scientific research documents, whether they are published or not. The documents may come from teaching and research institutions in France or abroad, or from public or private research centers.
L'archive ouverte pluridisciplinaire HAL, est destinée au dépôt et à la diffusion de documents scientifiques de niveau recherche, publiés ou non, émanant des établissements d'enseignement et de recherche français ou étrangers, des laboratoires publics ou privés. 


\title{
'Becoming a species by becoming a pest' or how two maize pests of the genus Ostrinia possibly evolved through parallel ecological speciation events
}

\author{
DENIS BOURGUET,* SERGINE PONSARD,†+§ \\ PHILIPPE AUDIOT,* JING LI $\uparrow \$ \S^{* *}$ and ZHEN-YING WANG $\S$ \\ *Centre de Biologie pour la Gestion des Populations (CBGP), UMR INRA-IRD-CIRAD-Montpellier SupAgro, Campus \\ International de Baillarguet, 34988 Montferrier-sur-Lez Cedex, France, †UMR 5174 EDB (Laboratoire Evolution E Diversité \\ Biologique), Université de Toulouse, ENFA, 118 route de Narbonne, F-31062 Toulouse, France, $\$$ UMR 5174 EDB, CNRS, \\ Université Paul Sabatier, F-31062 Toulouse, France, §State Key Laboratory for the Biology of the Plant Diseases and Insect \\ Pests, Institute of Plant Protection, Chinese Academy of Agricultural Sciences, No.2 West Yuanmingyuan Road, Beijing 100193, \\ China, IUMR 5175, CNRS, Centre d'Ecologie Fonctionnelle et Evolutive (CEFE), 1919 route de Mende, Montpellier Cedex 05, \\ 34293 Montpellier, France, **School of biological technology, Xi'an University of Arts and Science, No.168 South Taibai Road, \\ Xi'an, Shaanxi Province 710065, China
}

\begin{abstract}
New agricultural pest species attacking introduced crops may evolve from pre-existing local herbivores by ecological speciation, thereby becoming a species by becoming a pest. We compare the evolutionary pathways by which two maize pests (the Asian and the European corn borers, ACB and ECB) in the genus Ostrinia (Lepidoptera, Crambidae) probably diverged from an ancestral species close to the current Adzuki bean borer (ABB). We typed larval Ostrinia populations collected on maize and dicotyledons across China and eastern Siberia, at microsatellite and mitochondrial loci. We found only two clusters: one on maize (as expected) and a single one on dicotyledons despite differences in male mid-tibia morphology, suggesting that all individuals from dicotyledons belonged to the ABB. We found evidence for migrants and hybrids on both host plant types. Hybrids suggest that field reproductive isolation is incomplete between ACB and ABB. Interestingly, a few individuals with an 'ABB-like' microsatellite profile collected on dicotyledons had 'ACB' mtDNA rather than 'ABB-like' mtDNA, whereas the reverse was never found on maize. This suggests asymmetrical gene flow directed from the ACB towards the ABB. Hybrids and backcrosses in all directions were obtained in no-choice tests. In laboratory conditions, they survived as well as parental strain individuals. In Xinjiang, we found ACB and ECB in sympatry, but no hybrids. Altogether, our results suggest that reproductive isolation between $A C B$ and $A B B$ is incomplete and mostly prezygotic. This points to ecological speciation as a possible evolutionary scenario, as previously found for ECB and ABB in Europe.

Keywords: ecological speciation, microsatellites, mitochondrial DNA, Ostrinia furnacalis, Ostrinia nubilalis, Ostrinia scapulalis
\end{abstract}

Correspondence: Denis Bourguet, Fax: +33 4996233 45;

E-mail: bourguet@supagro.inra.fr

This article is dedicated to the memory of Serge Meusnier.

\section{Introduction}

When introduced into a new environment, plants may be attacked by herbivores. These may be pre-existing local species that simply include the new plant into 
their host range (e.g. Carroll et al. 2005), or they can be new species that evolve from the local fauna by shifting to this new host. The apple maggot Rhagoletis pomonella (Feder et al. 2003), which probably evolved by shifting from local hawthorn to introduced apple trees, is a famous example of the latter case, where becoming a species by means of ecological speciation (Schluter 2001, 2009; Rundle \& Nosil 2005; Matsubayashi et al. 2010) is facilitated by becoming a pest on a newly introduced plant. Investigating and comparing how this happens in several case studies can help in understanding the origin of certain agricultural pest species attacking introduced crops.

Crops are usually introduced on purpose and are directly facilitated by humans, so that they spread particularly rapidly over large areas, offering a new and abundant resource to phytophagous insects. Other things being equal, this should facilitate herbivore adaptation to such host plants. Indeed, large differences in abundance between taxa feeding in different habitats (here, feeding on local wild plants versus an introduced crop) should cause asymmetric gene flow, favouring alleles that confer good adaptation to the denser habitat (Lenormand 2012). A positive feedback loop occurs because these alleles, by ensuring a higher fitness on the introduced crop, increase the density of populations feeding on it, thereby amplifying density differences and thus the asymmetry of the gene flow between the two habitats, which further facilitates the increase in the frequency of alleles that are beneficial in the new crop. Because the ratio of the densities is as effective as the squared ratio between selection inside versus outside the habitat (Lenormand 2012), this feedback is likely to be particularly strong in populations feeding on crops that are widely cultivated.

Local adaptation does not always lead to speciation (Hendry 2009; Nosil et al. 2009a), but it selects for traits that promote premating isolation, which in turn increases the recruitment and frequency of beneficial alleles. This reinforcement loop (Lenormand 2012), if sufficiently strong, leads to the evolution of reproductive barriers that decrease and may ultimately interrupt gene flow between populations feeding on the introduced crop and those feeding on native host plants, resulting in the emergence of a new agricultural pest species from the local fauna.

Crops are often introduced into multiple geographical areas: each introduction is an additional opportunity for a new pest species to arise, as documented for instance in the pea aphid Acyrthosiphon pisum (Peccoud \& Simon 2010). Populations feeding on a given crop in different locations may show varying levels of progress towards ecological speciation. This variation provides the substrate to study factors that promote and constrain progress along the speciation continuum (Elias et al. 2012).

Our aim here is to compare two apparently parallel (Schluter \& Nagel 1995; Rosenblum \& Harmon 2011) evolutionary pathways by which two pest species of maize (Zea mays L.) evolved in the genus Ostrinia (Lepidoptera, Crambidae). Maize was introduced from America into Eurasia - the native range of most Ostrinia spp. - in at least two different geographical areas: Western Europe and Eastern Asia. Both introductions occurred at nearly the same time - approximately 500 years ago - and in both cases, its cultivation spread rapidly (Gay 1999). Today, maize is one of the three most cultivated crops worldwide, and its two major pests are the Asian corn borer (ACB), O. furnacalis Guenée, and the European corn borer (ECB), O. nubilalis Hübner.

The ACB occurs all over Eastern Asia and Oceania, but not in Europe (Mutuura \& Munroe 1970; All China Corn Borer Research Group 1988), while the reverse is true for the ECB (Mutuura \& Munroe 1970). In Xinjiang Province of northwestern China, several studies have reported the presence of both the ACB and ECB ( $\mathrm{Li} \&$ Gao 1985; Wang et al. 1995; Xu et al. 1998). Together with the history of maize cultivation, this geographical distribution suggests that the ACB and ECB diverged from each other in complete allopatry - the ECB somewhere in Europe and the ACB somewhere in Asia (see Alexandre et al. 2013, Fig. S1, Supporting information). Their current sympatry in Xinjiang Province, located in central Eurasia, probably corresponds to a recent secondary contact following the geographical spread of one or both species. This raises the question to what extent the - probably independent - evolutionary histories of these two maize pests might have paralleled one another.

Within the genus Ostrinia, the Adzuki bean borer (ABB), O. scapulalis Walker, is a close relative of both the ACB and the ECB (Kim et al. 1999). The ABB feeds on several dicotyledon species and ranges all over Eurasia, so it occurs in sympatry with the ECB in Europe and with the ACB in Asia. In Europe, several studies framed in an evolutionary perspective have compared the ECB/ABB species pair. They showed that these two species are morphologically identical except for adult males: ABB males can have mid-tibiae of three different types - small, medium or massive - whereas all ECB males have small mid-tibiae (Frolov et al. 2007, 2012). Larvae of both species are polyphagous, but they feed on different sets of host plants: ECB larvae are preferentially found on maize and $A B B$ larvae are mostly found on a number of dicotyledon species, notably mugwort (Artemisia vulgaris L.), hop (Humulus lupulus L.) and hemp (Cannabis sativa L.) (review in Ponsard 
et al. 2004; Leniaud et al. 2006; Frolov et al. 2007, 2012). Larval feeding performance (Calcagno et al. 2007) and oviposition preferences (Bethenod et al. 2005; Malausa et al. 2008) suggest that the two species are specialized on these respective host plant sets. Although the ABB and ECB are genetically differentiated (Bourguet et al. 2000; Martel et al. 2003; Thomas et al. 2003; Bontemps et al. 2004; Bethenod et al. 2005; Malausa et al. 2005, 2007a,b; Leniaud et al. 2006; Frolov et al. 2012), they still cross to a small extent in laboratory (Pélozuelo et al. 2007), semi-natural (Bethenod et al. 2005) and natural settings (Malausa et al. 2005, 2007a).

A number of studies have also been performed on $\mathrm{ACB}$ and $\mathrm{ABB}$ populations in Asia. Although genetically more differentiated than the European ECB/ABB pair (Kim et al. 1999), the ACB and the ABB are also morphologically very similar. The only obvious difference lies, once again, in the shape of the male mid-tibia. As in the ECB, all ACB males have small mid-tibiae. Asian $A B B$ males are reported to display only massive mid-tibiae (Mutuura \& Munroe 1970), although Frolov et al. (2007) argue that O. narynensis (medium male mid-tibiae) and O. orientalis (small male mid-tibiae), both feeding on dicotyledons, should probably be synonymized with O. scapulalis. The latter would thus be polymorphic for male mid-tibia size, as it has been shown to be in Europe (Frolov et al. 2012). Although polyphagous (Hattori \& Mutuura 1987; Ishikawa et al. 1999), ACB larvae preferentially feed on Poaceae, notably maize (Alpuerto 1985; Talekar et al. 1991; Lu et al. 1996), whereas, as in Europe, ABB larvae preferentially infest dicotyledon species, notably cocklebur (Xanthium spp.), hop (Humulus lupulus) and dock (Rumex spp.) (Ishikawa et al. 1999). Finally, females (males) of these species are known to produce (recognize) different sex pheromones (Ando et al. 1980 for the ACB and Huang et al. 1997 and Takanashi et al. 2005 for the ABB). These studies were mostly performed from taxonomic and agricultural perspectives. Hence, some key points for understanding the evolutionary relationships between the ACB and the ABB are still lacking, notably their levels of reproductive isolation and gene flow: are these different from those found in the $\mathrm{ECB} / \mathrm{ABB}$ pair in Europe, and are their characteristics compatible with an ecological speciation scenario?

To fill this gap, we investigated the genetic differentiation, gene flow and reproductive isolation between the $\mathrm{ABB}$ and the $\mathrm{ACB}$ in one hand, and between these two species and the ECB on the other hand. We used Ostrinia populations collected across China on maize and seven dicotyledon species, as well as previous European samples collected on the same host plant types by Frolov et al. (2012).

\section{Material and methods}

\section{Ostrinia populations and strains}

Natural populations. Diapausing Ostrinia larvae were collected at several sites in China and in one site in Khabarovsk (Eastern Russia), on two host plant types: maize (Zea mays L.) and dicotyledons [mugwort (Artemisia vulgaris L.), hop (Humulus lupulus L.), cocklebur (Xanthium spp.), goldenrod (Solidago canadensis L.), thistle (Cephalanoplos segetum (Bunge) Kitam), ragweed (Ambrosia trifida L.) and clematis (Clematis vitalba L.)]. A total of 12 and 16 populations were sampled on maize and dicotyledons, respectively.

Name, location and details of each sample are given in Table 1 and Fig. 1. Some of the larvae collected in 2009 were directly frozen at $-20{ }^{\circ} \mathrm{C}$ prior to genotyping. For some populations, another part of the sample was reared to the adult stage to determine male midtibia morphology (Table S1, Supporting information). All larvae collected in 2005 around Shanghai and Beijing were also reared to the adult stage, both to determine male mid-tibia morphology (Table S1, Supporting information) and to perform crosses and backcrosses. After mating, adults were frozen at $-20{ }^{\circ} \mathrm{C}$ prior to genotyping.

In addition, we used for comparative analyses a set of Ostrinia populations previously collected on maize and on two dicotyledons - mugwort and hemp (Cannabis sativa L.) - in Russia and Kazakhstan and analysed by Frolov et al. (2012). On the basis of microsatellite markers, populations from maize had been assigned to ECB, and populations from mugwort or hemp had been assigned to ABB (Frolov et al. 2012).

Strains. A French strain of ABB was established from approximately 50 diapausing larvae collected from mugwort near Paris (Ile-de-France, France, $48^{\circ} 46^{\prime} \mathrm{N}$, $02^{\circ} 04^{\prime} \mathrm{E}$ ) and Lille (Nord-Pas-de-Calais, France, $50^{\circ} 63^{\prime} \mathrm{N}$ $3^{\circ} 07^{\prime} \mathrm{E}$ ) in spring 2004. A French strain of ECB was founded with approximately 100 pupae taken from an outbred strain reared by INRA Le Magneraud. This strain originated from wild larvae collected from maize in the vicinity of Surgères (Poitou-Charentes, France, $\left.46^{\circ} 10^{\prime} \mathrm{N},-0^{\circ} 75^{\prime} \mathrm{E}\right)$. Finally, a Chinese strain of the ACB was founded with a mixture of individuals from the corresponding laboratory strains maintained at the State Key Laboratory of Biocontrol (Sun Yat-Sen University, Guangzhou, China) and the Institute of Plant Protection (Chinese Academy of Agricultural Sciences, Beijing, China). These strains had been founded with individuals obtained from wild ACB feeding on maize and 
Table 1 Ostrinia populations collected in China and Eastern Russia on maize and seven dicotyledon species. N corresponds to the number of individuals analysed

\begin{tabular}{|c|c|c|c|c|c|c|c|c|c|}
\hline Host plant type & Host species & Country & Region & Locality & Latitude & Longitude & Pop name & Year & $\mathrm{N}$ \\
\hline \multirow[t]{12}{*}{ Maize } & \multirow[t]{12}{*}{ Zea mays $\mathrm{L}$. } & Russia & Khabarovsk & Khabarovsk & $48^{\circ} 28^{\prime} \mathrm{N}$ & $135^{\circ} 00^{\prime} \mathrm{E}$ & KHA-M & 2005 & 50 \\
\hline & & \multirow[t]{11}{*}{ China } & Sichuan & Chengdu & $30^{\circ} 40^{\prime} \mathrm{N}$ & $104^{\circ} 04^{\prime} \mathrm{E}$ & CHE-M & 2009 & 26 \\
\hline & & & Yunnan & Kunming & $25^{\circ} 02^{\prime} \mathrm{N}$ & $102^{\circ} 43^{\prime} \mathrm{E}$ & KUN-M & 2009 & 29 \\
\hline & & & Guangdong & Shaoguan & $24^{\circ} 47^{\prime} \mathrm{N}$ & $113^{\circ} 35^{\prime} \mathrm{E}$ & SHA-M & 2009 & 30 \\
\hline & & & Liaoning & Shenyang & $41^{\circ} 48^{\prime} \mathrm{N}$ & $123^{\circ} 25^{\prime} \mathrm{E}$ & SHE-M & 2009 & 30 \\
\hline & & & Xinjiang & Urumqi & $43^{\circ} 49^{\prime} \mathrm{N}$ & $87^{\circ} 37^{\prime} \mathrm{E}$ & URU-M & 2009 & 27 \\
\hline & & & Hubei & Wuhan & $30^{\circ} 35^{\prime} \mathrm{N}$ & $114^{\circ} 18^{\prime} \mathrm{E}$ & WUH-M & 2009 & 30 \\
\hline & & & Xinjiang & Yining & $43^{\circ} 54^{\prime} \mathrm{N}$ & $81^{\circ} 19^{\prime} \mathrm{E}$ & YIN-M & 2009 & 28 \\
\hline & & & Beijing & Academy & $39^{\circ} 54^{\prime} \mathrm{N}$ & $116^{\circ} 23^{\prime} \mathrm{E}$ & ACA-M & 2005 & 29 \\
\hline & & & Hebei & Langfang & $39^{\circ} 30^{\prime} \mathrm{N}$ & $116^{\circ} 41^{\prime} \mathrm{E}$ & LAN-M & 2005 & 6 \\
\hline & & & Beijing & $\begin{array}{l}\text { Qian (Rian) } \\
\text { Sha Jian }\end{array}$ & $40^{\circ} 06^{\prime} \mathrm{N}$ & $116^{\circ} 09^{\prime} \mathrm{E}$ & RIA-M & 2005 & 20 \\
\hline & & & Shanghai & Shanghai & $31^{\circ} 14^{\prime} \mathrm{N}$ & $121^{\circ} 27^{\prime} \mathrm{E}$ & SHG-M & 2005 & 37 \\
\hline \multirow[t]{16}{*}{ Dicotyledons } & \multirow[t]{5}{*}{ Artemisia vulgaris L. } & & Sichuan & Chengdu & $30^{\circ} 40^{\prime} \mathrm{N}$ & $104^{\circ} 04^{\prime} \mathrm{E}$ & CHE-mu & 2009 & 29 \\
\hline & & & Yunnan & Kunming & $25^{\circ} 02^{\prime} \mathrm{N}$ & $102^{\circ} 43^{\prime} \mathrm{E}$ & KUN-mu & 2009 & 29 \\
\hline & & & Liaoning & Shenyang & $41^{\circ} 48^{\prime} \mathrm{N}$ & $123^{\circ} 25^{\prime} \mathrm{E}$ & SHE-mu & 2009 & 30 \\
\hline & & & Hubei & Wuhan & $30^{\circ} 35^{\prime} \mathrm{N}$ & $114^{\circ} 18^{\prime} \mathrm{E}$ & WUH-mu & 2009 & 24 \\
\hline & & & Beijing & Su Jia Tuo & $40^{\circ} 03^{\prime} \mathrm{N}$ & $116^{\circ} 08^{\prime} \mathrm{E}$ & SUJ-mu & 2005 & 71 \\
\hline & \multirow[t]{5}{*}{ Humulus lupulus L. } & & Guangdong & Shaoguan & $24^{\circ} 47^{\prime} \mathrm{N}$ & $113^{\circ} 35^{\prime} \mathrm{E}$ & SHA-ho & 2009 & 27 \\
\hline & & & Hubei & Wuhan & $30^{\circ} 35^{\prime} \mathrm{N}$ & $114^{\circ} 18^{\prime} \mathrm{E}$ & WUH-ho & 2009 & 31 \\
\hline & & & Shanghai & Shanghai & $31^{\circ} 14^{\prime} \mathrm{N}$ & $121^{\circ} 27^{\prime} \mathrm{E}$ & SHG-ho & 2005 & 37 \\
\hline & & & Beijing & Academy & $39^{\circ} 54^{\prime} \mathrm{N}$ & $116^{\circ} 23^{\prime} \mathrm{E}$ & ACA-ho & 2005 & 33 \\
\hline & & & Beijing & Su Jia Tuo & $40^{\circ} 03^{\prime} \mathrm{N}$ & $116^{\circ} 08^{\prime} \mathrm{E}$ & SUJ-ho & 2005 & 110 \\
\hline & \multirow[t]{2}{*}{ Xanthium spp. } & & Guangdong & Shaoguan & $24^{\circ} 47^{\prime} \mathrm{N}$ & $113^{\circ} 35^{\prime} \mathrm{E}$ & SHA-xa & 2009 & 35 \\
\hline & & & Hubei & Wuhan & $30^{\circ} 35^{\prime} \mathrm{N}$ & $114^{\circ} 18^{\prime} \mathrm{E}$ & WUH-xa & 2009 & 31 \\
\hline & Solidago canadensis L. & & Hubei & Wuhan & $30^{\circ} 35^{\prime} \mathrm{N}$ & $114^{\circ} 18^{\prime} \mathrm{E}$ & WUH-so & 2009 & 30 \\
\hline & $\begin{array}{l}\text { Cephalanoplos segetum } \\
\text { (Bunge) Kitam }\end{array}$ & & Hebei & Langfang & $39^{\circ} 30^{\prime} \mathrm{N}$ & $116^{\circ} 41^{\prime} \mathrm{E}$ & LAN-sa & 2005 & 16 \\
\hline & Ambrosia trifida L. & & Liaoning & Shenyang & $41^{\circ} 48^{\prime} \mathrm{N}$ & $123^{\circ} 25^{\prime} \mathrm{E}$ & SHE-tr & 2009 & 30 \\
\hline & $\begin{array}{l}\text { Clematis vitalba } \mathrm{L} . \text { and } \\
\text { Ambrosia trifida } \mathrm{L} \text {. }\end{array}$ & & Yunnan & Kunming & $25^{\circ} 02^{\prime} \mathrm{N}$ & $102^{\circ} 43^{\prime} \mathrm{E}$ & KUN-cl & 2009 & 16 \\
\hline
\end{tabular}

collected as overwintering larvae in Hangzhou (Zheijiang Province) and Hengshui (Hebei Province), respectively.

\section{Genotyping}

Genomic DNA was isolated from part of each larva using either PureGene (Gentra Systems) or DNeasy Blood and Tissue (Qiagen) extraction kits, or a standard phenol-chloroform procedure (Sambrook et al. 1989). All individuals were genotyped at 8 autosomal microsatellite loci: T81, D145, D243, D63, D65, Ga54, OnT2 and OnT3. Locus Ga54 was developed by Brad S Coates (United States Department of Agriculture). The other loci are described in the study by Dalecky et al. (2006) and Kim et al. (2008). This set of microsatellite loci is the same as that used by Frolov et al. (2012) to genotype the Russian and Kazakh populations. Consistency of allele scoring between Russian/Kazakh and Chinese populations was carefully checked between successive series of analyses by including previously scored samples into each run. Alleles were scored using the software GENEMAPPER 4.0 (Applied Biosystems, Foster City, CA, USA).

\section{Genetic clustering}

Bayesian clustering analyses were conducted using the software STRUCTURE (Pritchard et al. 2000). STRUCTURE, version 2.3.1. (Hubisz et al. 2009), offers an extension of the previous STRUCTURE model, making it possible to use available information about 'sampling locations' (sensu lato, i.e, geographical location or host plant). This information is used as a prior and more prior weight is placed on clustering outcomes that are correlated with this sampling information. STRUCTURE 2.3.1 detects structure at low levels of divergence, or with less data, and is not biased towards erroneously detecting structure when it is not present (Hubisz et al. 2009). When analysing structured data sets for increasing values of $K$, the most divergent groups are expected to separate into distinct clusters first (Pritchard et al. 2000; Fontaine et al. 2007). We varied the number of putative 


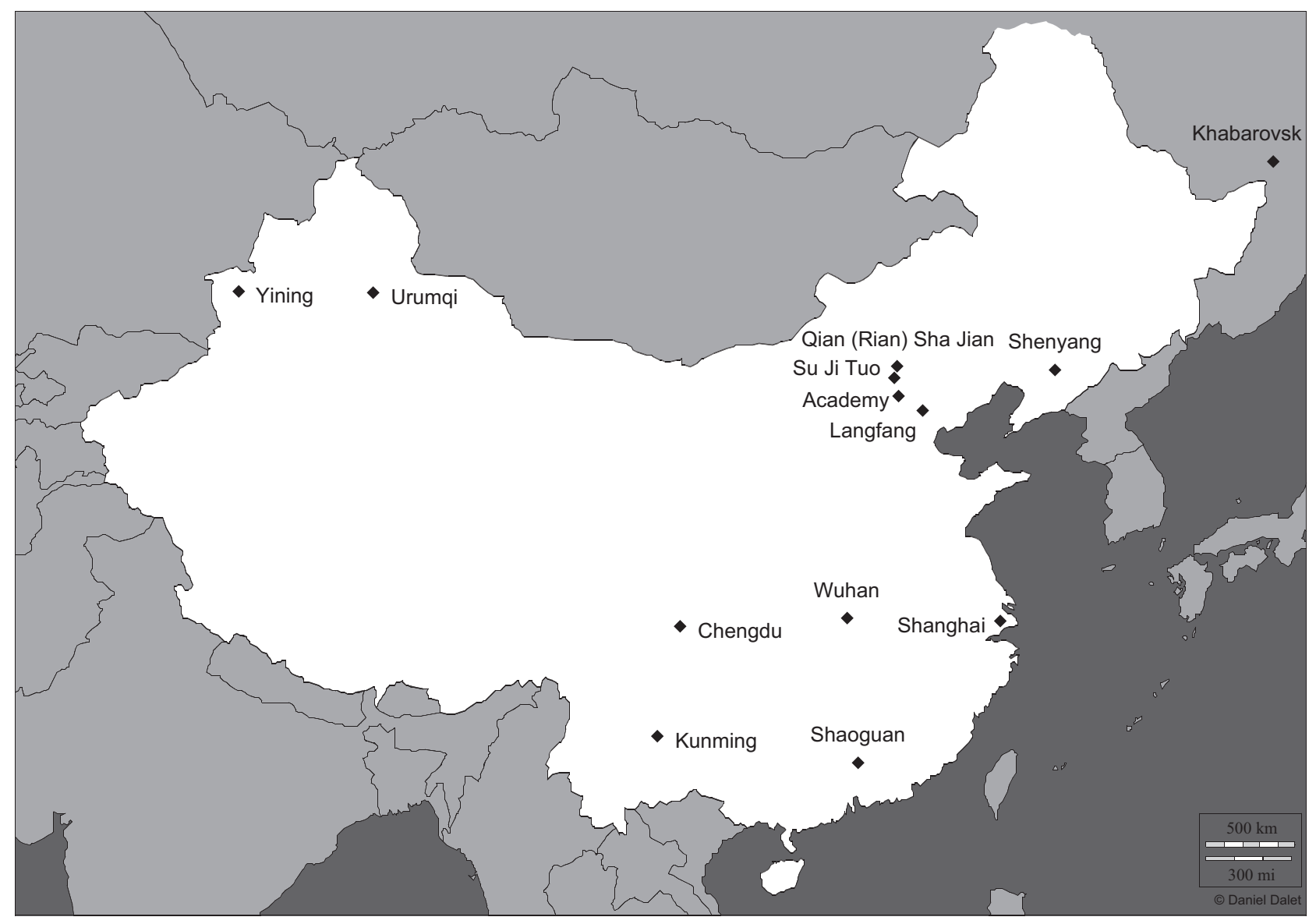

Fig. 1 Map of the sampling sites in China and Eastern Russia.

clusters $(K)$ between 1 and 6 and performed 20 independent runs for each value of $K$. Each Markov chain was run for 200000 steps, after a 50 000-step burn-in period, using the admixture model for correlations of allele frequencies across clusters, with the default value for parameter $\alpha$ and the default prior for $F_{S T}$.

Following Evanno et al. (2005), we computed the statistic $\Delta K$, which is based on the rate of change in the $\log$ posterior probability of the data between successive values of $K$, to detect the uppermost hierarchical level of structure. Finally, we used the 'greedy' algorithm implemented in the software CLUMPP (Jakobsson \& Rosenberg 2007) to detect possible distinct modes among the results of the set of 20 independent runs obtained for any given value of $K$. For $K=3$ and $K=5$, two modes were observed, while for other values of $K$, all replicates corresponded to a single mode.

\section{Genetic assignment}

Mitochondrial DNA. Although they are genetically differentiated at several nuclear loci, no differentiation was found between the ABB and the ECB at mitochon- drial loci (Martel et al. 2003). In contrast, the mitochondrial genomes of the ACB and the ECB and those of the $A C B$ and the $A B B$ are significantly differentiated from each other (Coates et al. 2005). Among several mitochondrial loci, the cytochrome oxydase subunit 1 (COI) appears to be one of the most differentiated between the ACB on the one hand and the two other species on the other hand (S. Ponsard, unpublished data) and was therefore used here to assign individuals either to the $\mathrm{ACB}$ or to the ECB/ABB.

For all individuals, we amplified a 1200 -bp fragment of COI using primers COI_F1 (5'-CAA GAA GAA TCG TTG AAA ATG GAG C-3') and COI_R1 (5'-TGG AAG TTC GTT ATA TGA ATG TTC TGC-3') and the following PCR procedure: $5 \mathrm{~min}$ at $95{ }^{\circ} \mathrm{C}, 35$ cycles of $20 \mathrm{~s}$ at $95^{\circ} \mathrm{C}, 20 \mathrm{~s}$ at $55^{\circ} \mathrm{C}$ and $40 \mathrm{~s}$ at $72{ }^{\circ} \mathrm{C}$, followed by $10 \mathrm{~min}$ at $72{ }^{\circ} \mathrm{C}$.

Two separate digestions of the PCR products were performed: one with restriction enzyme ClaI and one with VspI. These two enzymes were chosen following a preliminary analysis of the amplified COI fragment of two individuals collected in European maize fields (presumably ECB), six individuals collected in Asian 
maize fields (presumably $\mathrm{ACB}$ ) and 13 individuals from dicotyledons (presumably ABB) collected worldwide (S. Ponsard, unpublished data). This analysis showed that the COI fragment contained a ClaI restriction site shared by all individuals collected on maize in Europe and $85 \%$ individuals from dicotyledons. Conversely, this restriction site was absent in all Asian individuals collected on maize. The COI fragment also contained two $V s p$ I restriction sites: one shared by all individuals regardless of host plant and geographical origin and one found in all individuals collected on maize in Asia, but absent in both individuals collected in Europe on maize and in $77 \%$ of the individuals sampled on dicotyledons. Based on these results, we defined four ClaI-VspI mitochondrial types: $a c b-a c b, a c b-a b b / e c b, a b b /$ $e c b-a c b$ and $a b b / e c b-a b b / e c b$. With this classification, Asian and European individuals collected on maize were $a c b-a c b$ and $a b b / e c b-a b b / e c b$, respectively. On dicotyledons, 10 were $a b b / e c b-a b b / e c b$, 2 were $a c b$ - $a c b$, and 1 was $a c b-a b b / e c b$.

Microsatellite loci. We used the Bayesian approach of genetic clustering implemented in NEWHYBRIDS 1.1 (Anderson \& Thompson 2002) to assign all individuals - except those collected at Yining (Xinjiang, northwestern China) on maize which mostly belong to ECB (see Results) - to $\mathrm{ABB}$, to $\mathrm{ACB}$ or to introgressed genotypes. NEWHYBRIDS assigns individuals to six pedigree classes (i.e. two F0 classes or 'parental species', F1 and F2 hybrids, and two backcross classes corresponding to F1 introgressed by either one or the other parental species). It then computes for each individual the posterior probability that it belongs to each class by Markov chain Monte Carlo.

Here, we defined the two F0 classes, respectively, as ACB and ABB. Anderson and Thompson (2002) have noted that NEWHYBRIDS requires the presence of diagnostic alleles to distinguish the respective genotype frequencies of distinct hybrid classes (F1 vs. F2 and backcrosses). As none of the loci studied here was completely diagnostic (see Results) and as the total number of loci was rather limited, distinguishing between the different hybrid classes was proved impossible. Thus, as suggested by Vähä and Primmer (2006), who tested the efficiency of NEWHYBRIDS for the detection of hybrids in simulated data sets, we summed the posterior probability values for all hybrid classes for any given individual and used this sum as a single estimate. Probabilities assigning individuals to one of the two species (ABB or ACB) or to a 'hybrid' (introgressed genotype) between these two taxa were obtained from 200000 steps following a burn-in of 20000 steps. We considered individuals that were not assigned to one of these three classes with a probability of $>95 \%$ as 'unassigned'.

\section{Genetic differentiation and IBD}

For each population, we excluded all individuals that were not assigned to a probability $>95 \%$ to either $\mathrm{ACB}$ or $\mathrm{ABB}$ according to their genotype at microsatellite loci. Based on the resulting data set, we then analysed the genetic differentiation within and between the two species throughout China and Eastern Russia.

Over all the $\mathrm{ACB}$ and $\mathrm{ABB}$ populations, the genetic diversity at each microsatellite locus was calculated using FSTAT 2.8 (Goudet 1999). For each ABB and ACB population, we tested for deviation from Hardy Weinberg equilibrium (HWE) for each locus and over all loci using Fisher's exact test as implemented in GENEPOP 4.0 (Rousset 2008). When a significant deviation from HWE was detected at a particular locus, we used the program MICRO-CHECKER (van Oosterhout et al. 2004) to determine whether the deviation was likely to be due to the presence of null alleles or to any other genotyping errors. In all cases, the presence of null alleles was found to be the most likely explanation (see Results).

For each locus and across all loci, we estimated the pairwise $F_{\mathrm{ST}}$ (Weir \& Cockerham 1984) between each pair of populations. To this effect, we applied the ENA correction as implemented in FREENA (Chapuis \& Estoup 2007) to correct for the bias due to the presence of null alleles at several loci (see Results). This corrected $F_{\mathrm{ST}}$ estimator will be referred to as $F_{\mathrm{ST}}{ }^{\{\mathrm{ENA}\}}$. The lower and upper bounds of the $95 \%$ confidence intervals of $F_{\mathrm{ST}}{ }^{{ }^{[E N A\}}}$ were obtained using FREENA, taking the 2.5\% and $97.5 \%$ quantiles of the distributions of bootstrapped global $F_{\mathrm{ST}}{ }^{\{\mathrm{ENA}\}}$ values generated by 5000 resamplings (Chapuis \& Estoup 2007).

Isolation-by-distance (IBD) patterns were assessed by testing for independence between geographical [ $\ln ($ geographical distance)] and genetic distances $\left[F_{\mathrm{ST}}{ }^{\{\mathrm{ENA}\}} /\right.$ $\left.\left(1-F_{\mathrm{ST}}{ }^{(\mathrm{ENA})}\right)\right]$ among populations collected on each host plant type - maize vs. dicotyledons - as described by Rousset (1997). The null hypothesis that genetic and geographical distances are independent was tested (using GENEPOP 4.0) against the alternative hypothesis that they are positively correlated, as expected in case of significant IBD.

\section{Mating success}

Diapausing larvae collected around Shanghai and Beijing in 2005 were kept at $4{ }^{\circ} \mathrm{C}$ for several weeks to allow diapause completion. They were then placed in plastic boxes with a moist piece of cotton, maintained at $25{ }^{\circ} \mathrm{C}$ under a $16: 8 \mathrm{~h}$ light/dark (L:D) photoperiod. The larvae were checked every $72 \mathrm{~h}$ for individuals that had undergone pupation. 
Male and female pupae from all populations and strains were kept separately, so that adults were all virgin prior to being used to perform crosses and backcrosses. We aimed at obtaining 50 mating pairs for each type of cross or backcross. Each pair was placed in a cylindrical plastic box (8.5 cm diameter, $11 \mathrm{~cm}$ deep) containing a moist piece of cotton and a $15 \times 1.5 \mathrm{~cm}$ strip of paper for resting and oviposition. We used virgin females and males that had emerged $<24 \mathrm{~h}$ ago. They were paired and allowed to mate during 3 consecutive nights at $25^{\circ} \mathrm{C}$ and under a 16:8 $\mathrm{h} \mathrm{L} / \mathrm{D}$ photoperiod. At the end of the third night, females were killed and dissected to determine their mating status - virgin or mated - according to the content of the bursa copulatrix in their genital duct (Pélozuelo et al. 2007). Indeed, the sperm and nutritious substances transferred by males during mating form an easily recognizable solidified structure, the spermatophore (one per mating event), that is later used by the female to fertilize her oocytes. Thus, our estimate of mating success for a given category is the percentage of females that were found to carry at least one spermatophore.

\section{Hybrid fitness}

To explore possible post-zygotic isolation between $A B B$, ECB and ACB, we raised eggs obtained from hybrid and intraspecies crosses to adult stage at $25{ }^{\circ} \mathrm{C}$ under a 16:8 h L/D photoperiod. Larvae were fed on a standard artificial corn-based diet. We calculated the average $\%$ of hatching, the average number of first instars (L1) and the\% of survival at different life stages: from first (L1) to fifth (L5) instar, from L5 to pupation and from pupation to adult emergence.

\section{Results}

\section{Genetic clustering with microsatellite data}

We found a very clear separation into two clusters among Ostrinia larvae collected in China and Eastern Russia. One cluster included all populations collected on maize except that from Yining (Xinjiang, northwestern China). A second cluster included all populations collected on dicotyledons, as well as the population collected from maize at Yining (Fig. 2, Evanno et al.'s (2005) $\Delta K$ statistic being maximum for $K=2$ ). When increasing the number of clusters up to $K=6$, all populations collected on maize - except Yining - were mostly assigned to a single cluster regardless of geographical origin, and this cluster never included any population collected on dicotyledons (Fig. 2). For $K=3$, the global dichotomy between maize and dicotyledons remained, and a third group appeared, consisting of nearly all individuals sampled at Yining on maize. For $K=4$, these three groups remained and a fourth one appeared, including the populations collected at Kunming on mugwort, Clematis vitalba and Ambrosia trifida. For $K>4$, these four groups remained and no further group emerged.

When including populations collected on maize and dicotyledons in Western Russia and Kazakhstan (Frolov et al. 2012) into our data set, two main clusters appeared: one 'Asian' containing all Chinese and Eastern Russian populations and one 'European' containing all populations collected in Western Russia and Kazakhstan (Fig. S1, Supporting information, $K=2$ ). This 'European' cluster also contained all but 5 individuals sampled from maize at Yining, the 5 remaining individuals clearly belonging to the 'Asian' cluster. From $K=3$ to 5 , these two main clusters each split into two subclusters: one containing all populations from maize and the other all populations from dicotyledons (Fig. S1, Supporting information). In Europe, the two subclusters correspond to the $\mathrm{ABB}$ (on dicotyledons) and the ECB (on maize) (Frolov et al. 2012). In Asia, the subclustering was consistent with the ABB (on dicotyledons) and the ACB (on maize).

\section{Genetic assignment with mitochondrial and microsatellite data}

We successfully typed the mitochondrial genome in 98 and $97 \%$ of the individuals collected on maize $(n=342)$

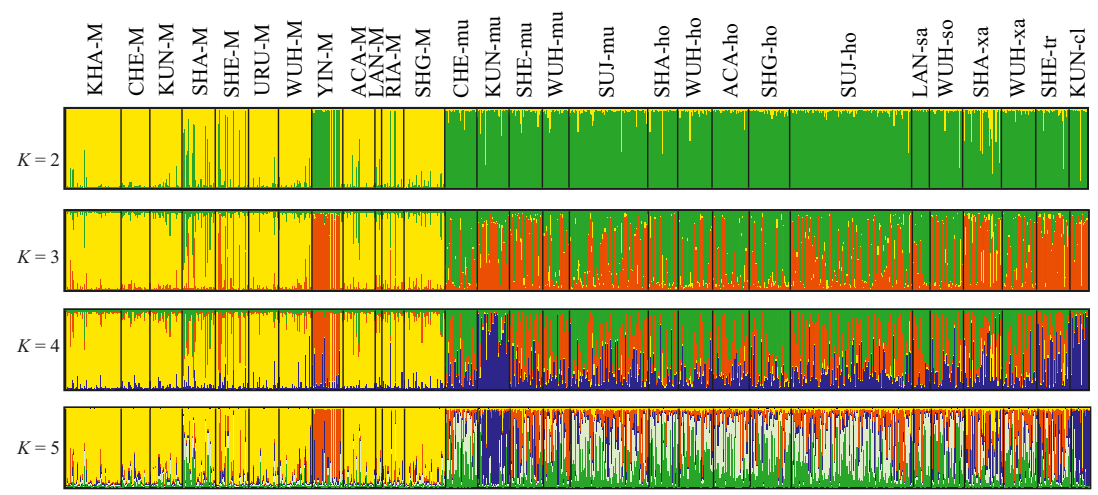

Fig. 2 Bayesian clustering analysis of populations collected on maize and dictotyledons in China and Eastern Russia, for $K=2$ to $K=5$. 
and dicotyledons $(n=579)$, respectively (Table 2$)$. Over all populations, 89 and $84 \%$ individuals collected on maize and on dicotyledons had $a c b-a c b$ and $a b b / e c b-a b b /$ $e c b$ mitochondrial types, respectively (Table 2). Individuals with unusual ClaI-VspI patterns ( $a c b-a b b / e c b$ or $a b b / e c b-a c b$ ) represented $10 \%$ of those collected on dicotyledons, but were never found on maize.

On dictotyledons, more than half of the populations contained $a c b-a c b$ individuals, but those individuals never represented more than approximately $10 \%$ of any particular population (Table 2). On maize, only three populations contained $a b b / e c b-a b b / e c b$ individuals, representing $10 \%, 23 \%$ and $82 \%$ of these populations, respectively (Table 2). The population including $82 \%$ $a b b / e c b-a b b / e c b$ individuals was that collected at Yining. Nuclear and mitochondrial assignments were perfectly consistent in this population: all 23 individuals that had an $a b b / e c b-a b b / e c b$ restriction pattern belonged to the
'European' cluster according to their microsatellite genotypes, whereas all $a c b-a c b$ individuals belonged to the 'Asian' cluster.

Using microsatellites, we were able to assign $54 \%$ of the individuals collected on maize - the population from Yining being excluded from this analysis because it contained mostly $a b b / e c b-a b b / e c b$-type larvae - and $78 \%$ of those collected on dicotyledons to $\mathrm{ACB}, \mathrm{ABB}$ or intermediate genotypes with a $95 \%$ probability (Table 3). On maize, $88 \%$ of them were assigned to ACB. All larvae collected on maize and assigned to ABB were found in two populations (SHE-M and RIA-M) where they represented a substantial proportion of individuals. More than half of the populations contained intermediate genotypes, at rates ranging from 5\% to $100 \%$ (Table 3). On dicotyledons, individuals were assigned either to ABB (96\%) or to intermediate genotypes (4\%), but never to ACB. As on maize, intermediate

Table 2 Genetic assignment to one of the four mitochondrial types

\begin{tabular}{|c|c|c|c|c|c|c|c|}
\hline \multirow[b]{2}{*}{ Host plant } & \multirow[b]{2}{*}{ Population } & \multirow[b]{2}{*}{$\mathrm{N}$ ind } & \multicolumn{5}{|c|}{$\%$ assignment (ClaI-VspI) } \\
\hline & & & $a c b-a c b$ & $a b b / e c b-a b b / e c b$ & $a c b-a b b / e c b$ & $a b b / e c b-a c b$ & Unassigned* \\
\hline \multirow[t]{13}{*}{ Maize } & CHE-M & 26 & 96 & 0 & 0 & 0 & 4 \\
\hline & KUN-M & 29 & 100 & 0 & 0 & 0 & 0 \\
\hline & SHA-M & 30 & 100 & 0 & 0 & 0 & 0 \\
\hline & SHE-M & 30 & 77 & 23 & 0 & 0 & 0 \\
\hline & URU-M & 27 & 96 & 0 & 0 & 0 & 4 \\
\hline & WUH-M & 30 & 100 & 0 & 0 & 0 & 0 \\
\hline & YIN-M & 28 & 14 & 82 & 0 & 0 & 4 \\
\hline & ACA-M & 29 & 97 & 0 & 0 & 0 & 3 \\
\hline & LAN-M & 6 & 100 & 0 & 0 & 0 & 0 \\
\hline & RIA-M & 20 & 90 & 10 & 0 & 0 & 0 \\
\hline & SHG-M & 37 & 95 & 0 & 0 & 0 & 5 \\
\hline & KHA-M & 50 & 100 & 0 & 0 & 0 & 0 \\
\hline & Total & 342 & 89 & 9 & 0 & 0 & 2 \\
\hline \multicolumn{8}{|l|}{ Dicotyledons } \\
\hline \multirow[t]{5}{*}{ Mugwort } & CHE-mu & 29 & 0 & 93 & 3 & 0 & 3 \\
\hline & KUN-mu & 29 & 3 & 86 & 0 & 0 & 10 \\
\hline & SHE-mu & 30 & 0 & 93 & 3 & 3 & 0 \\
\hline & WUH-mu & 24 & 0 & 96 & 0 & 4 & 0 \\
\hline & SUJ-mu & 71 & 0 & 75 & 0 & 20 & 6 \\
\hline \multirow[t]{5}{*}{ Hop } & SHA-ho & 27 & 7 & 85 & 0 & 0 & 7 \\
\hline & WUH-ho & 31 & 3 & 81 & 0 & 3 & 13 \\
\hline & SHG-ho & 37 & 11 & 86 & 0 & 3 & 0 \\
\hline & ACA-ho & 33 & 0 & 76 & 0 & 24 & 0 \\
\hline & SUJ-ho & 110 & 5 & 74 & 0 & 21 & 1 \\
\hline \multirow[t]{2}{*}{ Cocklebur } & SHA-xa & 35 & 0 & 94 & 3 & 0 & 3 \\
\hline & WUH-xa & 31 & 6 & 84 & 0 & 10 & 0 \\
\hline Goldenrod & WUH-so & 30 & 7 & 87 & 0 & 3 & 3 \\
\hline Thistle & LAN-sa & 16 & 6 & 88 & 6 & 0 & 0 \\
\hline Ragweed & SHE-tr & 30 & 0 & 93 & 0 & 7 & 0 \\
\hline \multirow[t]{2}{*}{ Clematis \& Ragweed } & KUN-cl & 16 & 6 & 94 & 0 & 0 & 0 \\
\hline & Total & 579 & 3 & 84 & 1 & 9 & 3 \\
\hline
\end{tabular}

*individuals with either no PCR amplification or atypical restriction pattern at least for one of the two restriction enzymes. 
Table 3 Genetic assignment to the $\mathrm{ACB}$, to the $\mathrm{ABB}$ or to Intermediate Genotypes (Interm. Genot.) by means of microsatellite genotypes

\begin{tabular}{|c|c|c|c|c|c|c|}
\hline \multirow[b]{2}{*}{ Host plant } & \multirow[b]{2}{*}{ Population } & \multirow[b]{2}{*}{$\mathrm{N}$ ind } & \multirow[b]{2}{*}{$\%$ assigned } & \multicolumn{3}{|c|}{$\%$ among assigned individuals } \\
\hline & & & & $\mathrm{ACB}$ & $\mathrm{ABB}$ & Interm. Genot. \\
\hline \multirow[t]{12}{*}{ Maize } & CHE-M & 26 & 38.5 & 100.0 & 0.0 & 0.0 \\
\hline & KUN-M & 29 & 51.7 & 80.0 & 0.0 & 20.0 \\
\hline & SHA-M & 30 & 33.3 & 70.0 & 0.0 & 30.0 \\
\hline & SHE-M & 30 & 63.3 & 78.9 & 15.8 & 5.3 \\
\hline & URU-M & 27 & 59.3 & 100.0 & 0.0 & 0.0 \\
\hline & WUH-M & 30 & 43.3 & 100.0 & 0.0 & 0.0 \\
\hline & ACA-M & 29 & 69.0 & 85.0 & 0.0 & 15.0 \\
\hline & LAN-M & 6 & 33.3 & 0.0 & 0.0 & 100.0 \\
\hline & RIA-M & 20 & 45.0 & 77.8 & 22.2 & 0.0 \\
\hline & SHG-M & 37 & 54.1 & 80.0 & 0.0 & 20.0 \\
\hline & KHA-M & 50 & 72.0 & 100.0 & 0.0 & 0.0 \\
\hline & Total & 314 & 54.1 & 87.6 & 2.9 & 9.4 \\
\hline \multicolumn{7}{|l|}{ Dicotyledons } \\
\hline \multirow[t]{5}{*}{ Mugwort } & CHE-mu & 29 & 82.8 & 0.0 & 100.0 & 0.0 \\
\hline & KUN-mu & 29 & 75.9 & 0.0 & 95.5 & 4.5 \\
\hline & SHE-mu & 30 & 70.0 & 0.0 & 100.0 & 0.0 \\
\hline & WUH-mu & 24 & 75.0 & 0.0 & 94.4 & 5.6 \\
\hline & SUJ-mu & 71 & 76.1 & 0.0 & 96.3 & 3.7 \\
\hline \multirow[t]{5}{*}{ Hop } & SHA-ho & 27 & 96.3 & 0.0 & 96.2 & 3.8 \\
\hline & WUH-ho & 31 & 77.4 & 0.0 & 95.8 & 4.2 \\
\hline & SHG-ho & 37 & 62.2 & 0.0 & 100.0 & 0.0 \\
\hline & ACA-ho & 33 & 90.9 & 0.0 & 96.7 & 3.3 \\
\hline & SUJ-ho & 110 & 71.8 & 0.0 & 98.7 & 1.3 \\
\hline \multirow[t]{2}{*}{ Cocklebur } & SHA-xa & 35 & 80.0 & 0.0 & 67.9 & 32.1 \\
\hline & WUH-xa & 31 & 80.6 & 0.0 & 100.0 & 0.0 \\
\hline Goldenrod & WUH-so & 30 & 83.3 & 0.0 & 100.0 & 0.0 \\
\hline Thistle & LAN-sa & 16 & 93.8 & 0.0 & 100.0 & 0.0 \\
\hline Ragweed & SHE-tr & 30 & 80.0 & 0.0 & 95.8 & 4.2 \\
\hline \multirow[t]{2}{*}{ Clematis \& Ragweed } & KUN-cl & 16 & 93.8 & 0.0 & 100.0 & 0.0 \\
\hline & Total & 579 & 78.2 & 0.0 & 96.0 & 4.0 \\
\hline
\end{tabular}

genotypes were found in half of the populations. Their frequencies were low $(<6 \%)$, except in one population where they reached $32 \%$ (Table 3 ).

On maize, all individuals assigned to ACB or to intermediate genotypes by means of microsatellites (as well as those that could not be assigned) had an $a c b-a c b$ mitochondrial type (Table 4). On dicotyledons, $95 \%$ of the individuals assigned to ABB by means of microsatellites were $a b b /$ $e c b-a b b / e c b, a c b-a b b / e c b$ or $a b b / e c b-a c b$, but $2.5 \%$ were $a c b$ $a c b$ (Table 4). On dicotyledons, individuals with intermediate genotypes at microsatellites were mostly $a b b / e c b-a b b /$ $e c b$, and in a few cases $a b b / e c b-a c b$.

\section{Genetic diversity and genetic differentiation}

Over all populations, the gene diversity of the $A C B$ and the $\mathrm{ABB}$ was approximately similar at all loci but one (Table 5). The only exception was locus OnT2. At this locus, genetic diversity was 21 times lower in ACB than in $A B B$, and, within the $A C B$, it was also markedly lower at OnT2 than at other loci (Table 5).

Genotypic frequencies at all loci but one - D145 showed deviations from HWE in many populations (Table S2, Supporting information) due to very high $F_{\mathrm{IS}}$ estimates. According to the analyses performed with MICRO-CHECKER, these deficits in heterozygotes were most likely due to null alleles (details not shown).

The genetic differentiation was rather low and mostly nonsignificant, both among $\mathrm{ACB}$ and among $\mathrm{ABB}$ populations (Table 5 and Tables S3 and S4, Supporting information). This differentiation was unrelated $(P=0.868)$ to geographical distance among ACB populations and was significantly $(P=0.002)$, but weakly (slope $=0.003)$, related to geographical distance among ABB (Fig. S2, Supporting information). Within $\mathrm{ABB}$, this differentiation seemed also unrelated to male mid-tibiae morphology. Indeed, the highest $F_{\mathrm{ST}}{ }^{\{\mathrm{ENA}\}}$ estimate between population pairs including one fixed for small and one 
Table 4 Relationship between mitochondrial and microsatellite assignments

\begin{tabular}{|c|c|c|c|c|c|c|c|}
\hline \multirow[b]{2}{*}{ Host plant } & \multirow[b]{2}{*}{ Microsatellite assignment } & \multirow[b]{2}{*}{$\mathrm{N}$ ind } & \multicolumn{5}{|c|}{ Mitochondrial assignment (\%) } \\
\hline & & & $a c b-a c b$ & $a b b / e c b-a b b / e c b$ & $a c b-a b b / e c b$ & $a b b / e c b-a c b$ & Unassigned \\
\hline \multirow[t]{4}{*}{ Maize } & $\mathrm{ACB}$ & 149 & 99.3 & 0.0 & 0.0 & 0.0 & 0.7 \\
\hline & $\mathrm{ABB}$ & 5 & 0.0 & 100.0 & 0.0 & 0.0 & 0.0 \\
\hline & Interm. Genot. & 16 & 93.8 & 0.0 & 0.0 & 0.0 & 6.3 \\
\hline & Unassigned & 144 & 95.1 & 2.8 & 0.0 & 0.0 & 2.1 \\
\hline \multirow[t]{4}{*}{ Dicotyledons } & $\mathrm{ACB}$ & 0 & - & - & - & - & - \\
\hline & $\mathrm{ABB}$ & 435 & 2.5 & 85.5 & 0.9 & 8.5 & 2.5 \\
\hline & Interm. Genot. & 18 & 0.0 & 94.4 & 0.0 & 5.6 & 0.0 \\
\hline & Unassigned & 126 & 6.3 & 74.6 & 0.0 & 13.5 & 5.6 \\
\hline
\end{tabular}

Table 5 Gene diversity and genetic differentiation (pairwise $F_{S T}^{\{\mathrm{ENA}\}}$ ) among and between $\mathrm{ACB}$ and $\mathrm{ABB}$ populations

\begin{tabular}{|c|c|c|c|c|c|c|c|c|c|c|c|}
\hline \multirow[b]{3}{*}{ Locus } & \multicolumn{4}{|c|}{ Among ACB populations } & \multicolumn{4}{|c|}{ Among ABB populations } & \multicolumn{3}{|c|}{$\begin{array}{l}\text { Between } \mathrm{ACB} \text { and } \mathrm{ABB} \\
\text { populations }\end{array}$} \\
\hline & \multicolumn{4}{|l|}{$F_{\mathrm{ST}}\{\mathrm{ENA}\}$} & \multicolumn{4}{|l|}{$F_{\mathrm{ST}}\{\mathrm{ENA}\}$} & \multicolumn{3}{|l|}{$F_{\mathrm{ST}}\{\mathrm{ENA}\}$} \\
\hline & Gene diversity & Min & Max & Mean & Gene diversity & Min & Max & Mean & Min & $\operatorname{Max}$ & Mean \\
\hline Ga54 & 0.298 & -0.052 & 0.298 & 0.121 & 0.458 & -0.033 & 0.148 & 0.024 & -0.041 & 0.262 & 0.085 \\
\hline OnT2 & 0.034 & -0.092 & 0.165 & 0.009 & 0.708 & -0.017 & 0.343 & 0.097 & 0.389 & 0.776 & 0.612 \\
\hline OnT3 & 0.737 & -0.048 & 0.140 & 0.015 & 0.784 & -0.025 & 0.264 & 0.054 & -0.039 & 0.413 & 0.107 \\
\hline D145 & 0.390 & -0.073 & 0.284 & 0.022 & 0.599 & -0.022 & 0.137 & 0.003 & 0.259 & 0.694 & 0.402 \\
\hline D243 & 0.531 & -0.051 & 0.243 & 0.045 & 0.108 & -0.032 & 0.167 & 0.029 & 0.004 & 0.710 & 0.304 \\
\hline$D 63$ & 0.533 & -0.037 & 0.092 & 0.014 & 0.703 & -0.019 & 0.201 & 0.028 & -0.041 & 0.205 & 0.036 \\
\hline D65 & 0.797 & -0.129 & 0.600 & 0.108 & 0.703 & -0.030 & 0.060 & 0.004 & -0.040 & 0.289 & 0.102 \\
\hline T81 & 0.760 & -0.056 & 0.155 & 0.019 & 0.879 & -0.014 & 0.100 & 0.014 & 0.026 & 0.231 & 0.106 \\
\hline Across loci & - & -0.009 & 0.111 & 0.040 & - & -0.004 & 0.114 & 0.035 & 0.189 & 0.329 & 0.255 \\
\hline
\end{tabular}

fixed for massive mid-tibiae (Table S1, Supporting information) was 0.015 (between SUJ-mu and CHE-mu), and none was significantly different from 0 (Table S4, Supporting information).

Asian corn borer populations collected from maize were significantly differentiated from all ABB populations (Table S5, Supporting information) with $F_{\mathrm{ST}}{ }^{\{\mathrm{ENA}\}}$ values across loci ranging from 0.189 to 0.329 (Table 5). The mean genetic differentiation varied between the eight microsatellites. Five loci displayed mean $F_{\mathrm{ST}}{ }^{\{\mathrm{ENA}\}}$ values around 0.100 . The $F_{\mathrm{ST}}$ values at the three other loci were $0.304,0.402$ and 0.612 . The latter (and highest) value was found at OnT2. The mean $F_{\mathrm{ST}}{ }^{\{\mathrm{ENA}\}}$ value calculated across loci equalled 0.255.

\section{Reproductive isolation between species}

Mating success rates between the $\mathrm{ACB}$ and the two other Ostrinia species (ranging from 0\% to $48 \%$, Table 6) were much lower than those of intraspecies crosses (ranging from $41.4 \%$ to 90\%, Table 6). This result held for crossing experiments conducted both with strains and with natural populations. Noteworthy, despite a moderate mating success (24\%) between the ACB strain and the ECB strain, both males and females of the latter failed to mate with any ACB emerging from natural populations (Table 6). Hybridization rates between the French ECB strain and natural ABB populations collected in China reached approximately 50-60\% (Table 6).

Fecundity, fertility and survival - at all stages - of F1 hybrids between $\mathrm{ACB}$ and $\mathrm{ECB}$ on the one hand and between $A C B$ and $A B B$ on the other hand were of similar magnitudes as those recorded for the parental $A C B$ and ECB strains (Table 7).

Mating successes in F2 crosses - from $70 \%$ to $90 \%-$ and in all backcrosses with the ECB strain - from $75 \%$ to $95 \%$ - were as high as those recorded within parental strains. Backcrosses with the $\mathrm{ABB}$ and the $\mathrm{ACB}$ strains were less successful, notably when using males of those strains: hybrid females only mated with $21-55 \%$ of $A B B$ or ACB males (Table 6). 
Table 6 Crosses and backcrosses between ACB, ECB and ABB individuals obtained from natural populations (Pop) or laboratory strains (Strain) from China and France. $N$ corresponds to the number of mating pairs tested

\begin{tabular}{|c|c|c|c|c|c|}
\hline Type & Cross (female $\times$ male) & Female & Male & $N$ & $\%$ success \\
\hline \multirow[t]{7}{*}{ Intraspecies } & \multirow[t]{4}{*}{$\mathrm{ACB} \times \mathrm{ACB}$} & Pop-China & Pop-China & 50 & 74.0 \\
\hline & & Strain-China & Strain-China & 50 & 90.0 \\
\hline & & Strain-China & Pop-China & 50 & 60.0 \\
\hline & & Pop-China & Strain-China & 50 & 68.0 \\
\hline & $\mathrm{ECB} \times \mathrm{ECB}$ & Strain-France & Strain-France & 50 & 82.0 \\
\hline & \multirow[t]{2}{*}{$\mathrm{ABB} \times \mathrm{ABB}$} & Strain-France & Strain-France & 29 & 41.4 \\
\hline & & Pop-China & Pop-China & 145 & 64.8 \\
\hline \multirow[t]{14}{*}{$\mathrm{F} 1$} & \multirow[t]{4}{*}{$\mathrm{ACB} \times \mathrm{ABB}$} & Strain-China & Pop-China & 50 & 2.0 \\
\hline & & Pop-China & Pop-China & 50 & 2.0 \\
\hline & & Strain-China & Strain-France & 50 & 14.0 \\
\hline & & Pop-China & Strain-France & 39 & 2.6 \\
\hline & \multirow[t]{4}{*}{$\mathrm{ABB} \times \mathrm{ACB}$} & Pop-China & Strain-China & 50 & 48.0 \\
\hline & & Pop-China & Pop-China & 50 & 8.0 \\
\hline & & Strain-France & Strain-China & 50 & 36.0 \\
\hline & & Strain-France & Pop-China & 35 & 5.7 \\
\hline & \multirow[t]{2}{*}{$\mathrm{ACB} \times \mathrm{ECB}$} & Strain-China & Strain-France & 50 & 24.0 \\
\hline & & Pop-China & Strain-France & 50 & 0.0 \\
\hline & \multirow[t]{2}{*}{$\mathrm{ECB} \times \mathrm{ACB}$} & Strain-France & Strain-China & 50 & 24.0 \\
\hline & & Strain-France & Pop-China & 50 & 0.0 \\
\hline & $\mathrm{ABB} \times \mathrm{ECB}$ & Pop-China & Strain-France & 80 & 51.3 \\
\hline & $\mathrm{ECB} \times \mathrm{ABB}$ & Strain-France & Pop-China & 82 & 61.0 \\
\hline \multirow[t]{4}{*}{$\mathrm{F} 2$} & $(\mathrm{ACB} \times \mathrm{ECB}) \times(\mathrm{ACB} \times \mathrm{ECB})$ & Strain-China $\times$ Strain-France & Strain-China $\times$ Strain-France & 20 & 90.0 \\
\hline & $(\mathrm{ECB} \times \mathrm{ACB}) \times(\mathrm{ECB} \times \mathrm{ACB})$ & Strain-France $\times$ Strain-China & Strain-France $\times$ Strain-China & 20 & 90.0 \\
\hline & $(\mathrm{ACB} \times \mathrm{ABB}) \times(\mathrm{ACB} \times \mathrm{ABB})$ & Strain-China $\times$ Strain-France & Strain-China $\times$ Strain-France & 20 & 70.0 \\
\hline & $(\mathrm{ABB} \times \mathrm{ACB}) \times(\mathrm{ABB} \times \mathrm{ACB})$ & Strain-France $\times$ Strain-China & Strain-France $\times$ Strain-China & 19 & 84.2 \\
\hline \multirow[t]{16}{*}{ Backcrosses } & $\mathrm{ECB} \times(\mathrm{ACB} \times \mathrm{ECB})$ & Strain-France & Strain-China $\times$ Strain-France & 20 & 95.0 \\
\hline & $\mathrm{ECB} \times(\mathrm{ECB} \times \mathrm{ACB})$ & Strain-France & Strain-France $\times$ Strain-China & 20 & 75.0 \\
\hline & $(\mathrm{ECB} \times \mathrm{ACB}) \times \mathrm{ECB}$ & Strain-France $\times$ Strain-China & Strain-France & 20 & 75.0 \\
\hline & $(\mathrm{ACB} \times \mathrm{ECB}) \times \mathrm{ECB}$ & Strain-China $\times$ Strain-France & Strain-France & 20 & 75.0 \\
\hline & $\mathrm{ABB} \times(\mathrm{ACB} \times \mathrm{ABB})$ & Strain-France & Strain-China $\times$ Strain-France & 19 & 63.2 \\
\hline & $\mathrm{ABB} \times(\mathrm{ABB} \times \mathrm{ACB})$ & Strain-France & Strain-France $\times$ Strain-China & 18 & 66.7 \\
\hline & $(\mathrm{ACB} \times \mathrm{ABB}) \times \mathrm{ABB}$ & Strain-China $\times$ Strain-France & Strain-France & 18 & 38.9 \\
\hline & $(\mathrm{ABB} \times \mathrm{ACB}) \times \mathrm{ABB}$ & Strain-France $\times$ Strain-China & Strain-France & 19 & 21.1 \\
\hline & $\mathrm{ACB} \times(\mathrm{ACB} \times \mathrm{ECB})$ & Strain-China & Strain-China $\times$ Strain-France & 20 & 70.0 \\
\hline & $\mathrm{ACB} \times(\mathrm{ACB} \times \mathrm{ABB})$ & Strain-China & Strain-China $\times$ Strain-France & 20 & 45.0 \\
\hline & $\mathrm{ACB} \times(\mathrm{ECB} \times \mathrm{ACB})$ & Strain-China & Strain-France $\times$ Strain-China & 20 & 90.0 \\
\hline & $\mathrm{ACB} \times(\mathrm{ABB} \times \mathrm{ACB})$ & Strain-China & Strain-France $\times$ Strain-China & 20 & 70.0 \\
\hline & $(\mathrm{ACB} \times \mathrm{ECB}) \times \mathrm{ACB}$ & Strain-China $\times$ Strain-France & Strain-China & 20 & 35.0 \\
\hline & $(\mathrm{ACB} \times \mathrm{ABB}) \times \mathrm{ACB}$ & Strain-China $\times$ Strain-France & Strain-China & 20 & 45.0 \\
\hline & $(\mathrm{ECB} \times \mathrm{ACB}) \times \mathrm{ACB}$ & Strain-France $\times$ Strain-China & Strain-China & 20 & 55.0 \\
\hline & $(\mathrm{ABB} \times \mathrm{ACB}) \times \mathrm{ACB}$ & Strain-France $\times$ Strain-China & Strain-China & 20 & 50.0 \\
\hline
\end{tabular}

\section{Discussion}

Ostrinia furnacalis and O. scapulalis: two widely distributed species with specific host plants

Our data show that in China (except at Yining, see below) and Eastern Russia, Ostrinia larvae feeding on maize ( $n=314$ larvae from 11 different locations) and on dicotyledons $(n=579$ larvae collected on seven host plants in 10 locations) belong to only two main genetic taxa.
In all likelihood, the major taxon found on maize corresponds to the $\mathrm{ACB}$ and the one almost exclusively found on dicotyledons to the ABB. The level of genetic differentiation was similar among ABB populations and among $\mathrm{ACB}$ populations, but $\mathrm{ABB}$ populations displayed a significant genetic isolation by distance, which was not found in ACB populations (the latter being in agreement with previous findings: J. Li, B.S. Coates, K.S. Kim, D. Bourguet, S. Ponsard, K. He, Z.Y. Wang, unpublished data). Hence, across China, all Ostrinia populations we sampled from dicotyledons probably 
Table 7 Larval development - from egg hatching to adult stage - in parental strains and hybrids between the ACB, ABB and ECB

\begin{tabular}{|c|c|c|c|c|c|c|c|}
\hline \multirow[b]{2}{*}{ Type } & \multirow[b]{2}{*}{ Cross $($ female $\times$ male $)$} & \multirow[b]{2}{*}{$N$} & \multirow[b]{2}{*}{$\begin{array}{l}\% \text { hatching } \\
(\text { mean } \pm \text { SE) }\end{array}$} & \multirow[b]{2}{*}{$N \mathrm{L1}($ mean $\pm \mathrm{SE})$} & \multicolumn{3}{|c|}{$\%$ survival (mean $\pm \mathrm{SE}$ ) } \\
\hline & & & & & From L1 to L5 & From L5 to pupae & $\begin{array}{l}\text { From pupae to } \\
\text { adults }\end{array}$ \\
\hline \multirow[t]{2}{*}{ Intraspecies } & $\mathrm{ACB} \times \mathrm{ACB}$ & 10 & $97.70 \pm 0.03$ & $120.89 \pm 19.98$ & $77.51 \pm 0.12$ & $88.60 \pm 0.05$ & $93.00 \pm 0.04$ \\
\hline & $\mathrm{ECB} \times \mathrm{ECB}$ & 9 & $96.33 \pm 0.05$ & $113.29 \pm 12.82$ & $90.58 \pm 0.04$ & $95.58 \pm 0.02$ & $93.56 \pm 0.04$ \\
\hline \multirow[t]{4}{*}{$\mathrm{F} 1$} & $\mathrm{ACB} \times \mathrm{ABB}$ & 5 & $98.00 \pm 0.02$ & $122.38 \pm 23.60$ & $87.75 \pm 0.04$ & $80.87 \pm 0.09$ & $86.20 \pm 0.05$ \\
\hline & $\mathrm{ABB} \times \mathrm{ACB}$ & 6 & $96.67 \pm 0.05$ & $115.16 \pm 22.67$ & $84.69 \pm 0.09$ & $77.69 \pm 0.12$ & $87.78 \pm 0.09$ \\
\hline & $\mathrm{ACB} \times \mathrm{ECB}$ & 10 & $98.60 \pm 0.03$ & $135.12 \pm 41.50$ & $85.33 \pm 0.16$ & $79.30 \pm 0.09$ & $89.44 \pm 0.05$ \\
\hline & $\mathrm{ECB} \times \mathrm{ACB}$ & 6 & $95.67 \pm 0.05$ & $121.83 \pm 20.65$ & $90.04 \pm 0.10$ & $92.96 \pm 0.04$ & $89.04 \pm 0.07$ \\
\hline
\end{tabular}

belong to a single, truly polyphagous species: the ABB. This species can oviposit on maize, as ABB migrants were detected on maize at Shenyang and Beijing (this study) and possibly in Hebei Province (Li et al. 2003). However, such migrants were rare, in agreement with Ishikawa et al. (1999)'s statement that 'infestation of maize by O. scapulalis occurs occasionally, but it seems to be accidental'.

As expected, all ACB males displayed small midtibia. In contrast, we found male mid-tibia polymorphism (small and massive mid-tibiae) within and between populations collected on dicotyledons. Populations with massive male mid-tibia were not genetically differentiated from populations with small male midtibia. Dicotyledon-feeding populations with massive male mid-tibiae have been described by Mutuura and Munroe (1970) as O. scapulalis, the ABB. They described two further dicotyledon-feeding species that differed from the $\mathrm{ABB}$ only by male mid-tibia size: $O$. narynensis (medium mid-tibia) and O. orientalis (small mid-tibia). As hypothesized by Frolov et al. (2007, 2012), we found that individuals with medium and massive mid-tibiae collected from dicotyledons in the same location did not show any genetic differentiation, suggesting that 'O. narynensis' is not a distinct species, but simply refers to intraspecific polymorphism within the ABB. Our results strongly support that 'O. orientalis' - feeding on several dicotyledons and displaying small male midtibiae - also belong to the ABB sensu Frolov et al. (2007), all the more so as the female sex pheromone of ' $O$. orientalis' is the same as that of the ABB (Ishikawa et al. 1999; Takanashi et al. 2005) and probably the same as that of 'O. narynensis' (according to pheromone trap captures reported in Frolov 1984; but note that data are scarce). Together with evidence reported by Frolov et al. (2012), our results strengthen Frolov et al.'s (2007) proposition to synonymize O. orientalis and O. narynensis with O. scapulalis.

The main genetic differentiation between dicotyledon-feeding populations was found between Europe and Asia. In our analysis, they formed two separate genetic clusters. Whether this is merely due to our sampling of two ends of a continuous gradient (Europe and Eastern Asia, leaving out Siberian populations in between) or reflects the existence of 2 distinct taxa separated by a sharp genetic discontinuity (with or without overlapping geographical distribution) is unclear. To gain further insight into the precise taxonomic status of the $\mathrm{ABB}$ across Eurasia, analysing Siberian populations located between Europe and Eastern Asia and/or crossing East-Asian and European ABB populations would be the next step.

\section{Reproductive isolation between O. furnacalis, O. nubilalis and O. scapulalis}

As in the ECB-ABB species pair (Bethenod et al. 2005; Pélozuelo et al. 2007), we obtained successful interspecific hybridizations in both directions between ACB and $\mathrm{ABB}$ individuals in no-choice laboratory conditions, although at a lower rate than intraspecific crosses in the same conditions. We found no evidence for postzygotic isolation: male and female hybrids between the ABB and the ACB usually developed normally until adult stage, although hybrid fertility was not assessed. Likewise, Y. Thomas and D. Bourguet (unpublished observations) found no obvious postzygotic isolation with respect to survival until adult stage in the ECB-ABB species pair.

We also found introgressed genotypes (F1, F2 and/or backcrosses) in natural populations collected on both maize and dicotyledons. It has been shown that some (rare) $\mathrm{ACB}$ and ECB males are attracted both to the pheromone of their own species and to that of the opposite species (Roelofs et al. 2002; Linn et al. 2003, 2007). As the ABB and the ECB release and recognize the same sex pheromone blends (Ishikawa et al. 1999), hybridization between the $\mathrm{ACB}$ and the $\mathrm{ABB}$ in the field may be due to some reciprocal attraction by sex pheromone between the $\mathrm{ACB}$ and the $\mathrm{ABB}$ in breeding sites. As the ECB and the ABB (Malausa et al. 2007a), the $\mathrm{ACB}$ and the $\mathrm{ABB}$ can therefore be considered as sibling species (sensu Drès \& Mallet 2002). 
Larvae with intermediate genotypes at microsatellite loci had an ACB mitochondrial type when collected on maize and an $\mathrm{ABB}$ mitochondrial type when collected on dicotyledons. If these intermediate genotypes correspond mostly to F1 hybrids, this pattern can be easily explained by oviposition preferences (ABB: Bethenod et al. 2005; Bontemps et al. 2004 and Malausa et al. 2008; ACB: Alpuerto 1985; Talekar et al. 1991 and Lu et al. 1996). Indeed, there is no reason to expect that mating with a heterospecific male would change the oviposition preferences of a female.

Finally, our laboratory results show that the ACB and the $\mathrm{ECB}$ are not only isolated from the $\mathrm{ABB}$, but also from each other by at least short-range premating barriers. As these two pests also release and recognize different sex pheromones (Ishikawa et al. 1999) and produce different courtship ultrasounds (Takanashi et al. 2010), premating barriers may be even stronger in the field. Indeed, although the frequencies of ECB and $\mathrm{ACB}$ at Yining were 85 and $15 \%$, we found no larvae with an intermediate genotype: all individuals were assigned either to the ACB or to the ECB. Moreover, for those individuals, there was no discrepancy between the genetic assignment by means of microsatellites and their mitochondrial types, suggesting an absence of genetic introgression between the ECB and the ACB. It is possible that the ACB and the ECB are completely reproductively isolated from each other in the field, but at least in laboratory conditions, hybrids between these two pests are as fit as their parental counterparts, suggesting a lack of any incompatibilities, notably between the genes/alleles ensuring adaptation to maize in both species.

\section{Asymmetric gene flow between O. furnacalis and O. scapulalis}

On maize, all larvae assigned to the ACB by means of microsatellites had an ACB mitochondrial type. In contrast, on dicotyledons, a few larvae assigned to the ABB by means of microsatellites had an ACB rather than an ABB mitochondrial type. This suggests that although hybrids are found on both host plants (indicating that there is no drastic genetic and/or ecological selection against them, at least at larval stages), there is an asymmetric gene flow between these species - the introgression going from the ACB towards the ABB. Such asymmetric gene flow would explain why there is no male mid-tibia polymorphism in the ACB.

A plausible scenario that could account for such asymmetric gene flow is presented in Fig. 3. It requires (i) dominance in female preferences for oviposition preference for dicotyledons (as in the ABB) being dominant over the preference for maize (as in the
ACB) - and (ii) hybrid males preferentially mating with $\mathrm{ABB}$ rather than $\mathrm{ACB}$ females. The first point remains to be tested in Ostrinia, but it would not be unusual. Indeed, Matsubayashi et al. (2010) found that eight of 14 studies exploring the genetic basis of host preferences in phytophagous insects revealed that preference for one host was dominant over preference for the other. The second point is sustained by Domingue et al.'s (2008) findings. These authors showed that male hybrids between ECB and ACB displayed a greater tendency to fly upwind to the ECB pheromone than to the ACB pheromone. This was true for hybrid males from both reciprocal crosses. As the $A B B$ and ECB produce and recognize the same sex pheromone blend (Ishikawa et al. 1999), ACB-ABB hybrid males might also prefer the sex pheromones of the $\mathrm{ABB}$ over the ACB.

\section{Becoming a pest species by means of ecological speciation?}

Maize originates from America and has been introduced concurrently into Europe and Asia at the end of the 15th century (Gay 1999). In both areas, it is believed to have spread rapidly, being readily adopted by farmers. This crop thus offered European and Asian phytophagous insects a new and abundant resource onto which they could shift, specialize and become specific pests. Nowadays, both ECB and ACB are major pests of this crop, and both also are only partly reproductively isolated from the $\mathrm{ABB}$, a close congeneric species which feeds on dicotyledons. If reproductive isolation and adaptation to maize evolved concurrently and synergetically, the scenario corresponds to an ecological speciation event. Alternatively, reproductive isolation may have evolved long before and for reasons unrelated to adaptation to maize.

Divergent selection on a 'magic trait' (Gavrilets 2004) favouring both reproductive isolation and a better adaptation to maize is one possible mechanism for ecological speciation. No such candidate 'magic trait' has been documented yet in the ACB-ECB-ABB group except possibly some temporal isolation between the ABB and the ECB (Thomas et al. 2003 but see Malausa et al. 2005). More generally, we cannot exclude that the $\mathrm{ACB}$ and the ECB were already to some degree reproductively isolated from the ABB when maize was introduced into Europe and Asia. The ACB and the ECB may simply have included this crop into their host plant range, possibly without any further consequence on their reproductive isolation from the ABB. Such scenario is supported by the estimate of divergence time between ECB and ABB in Western Europe produced by Malausa et al. (2007b) - a time that appears older than 


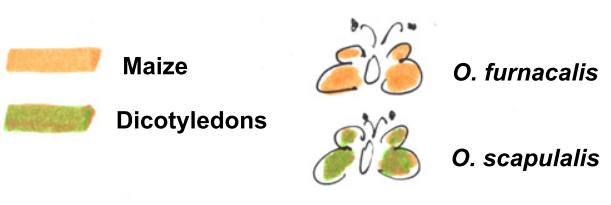

A
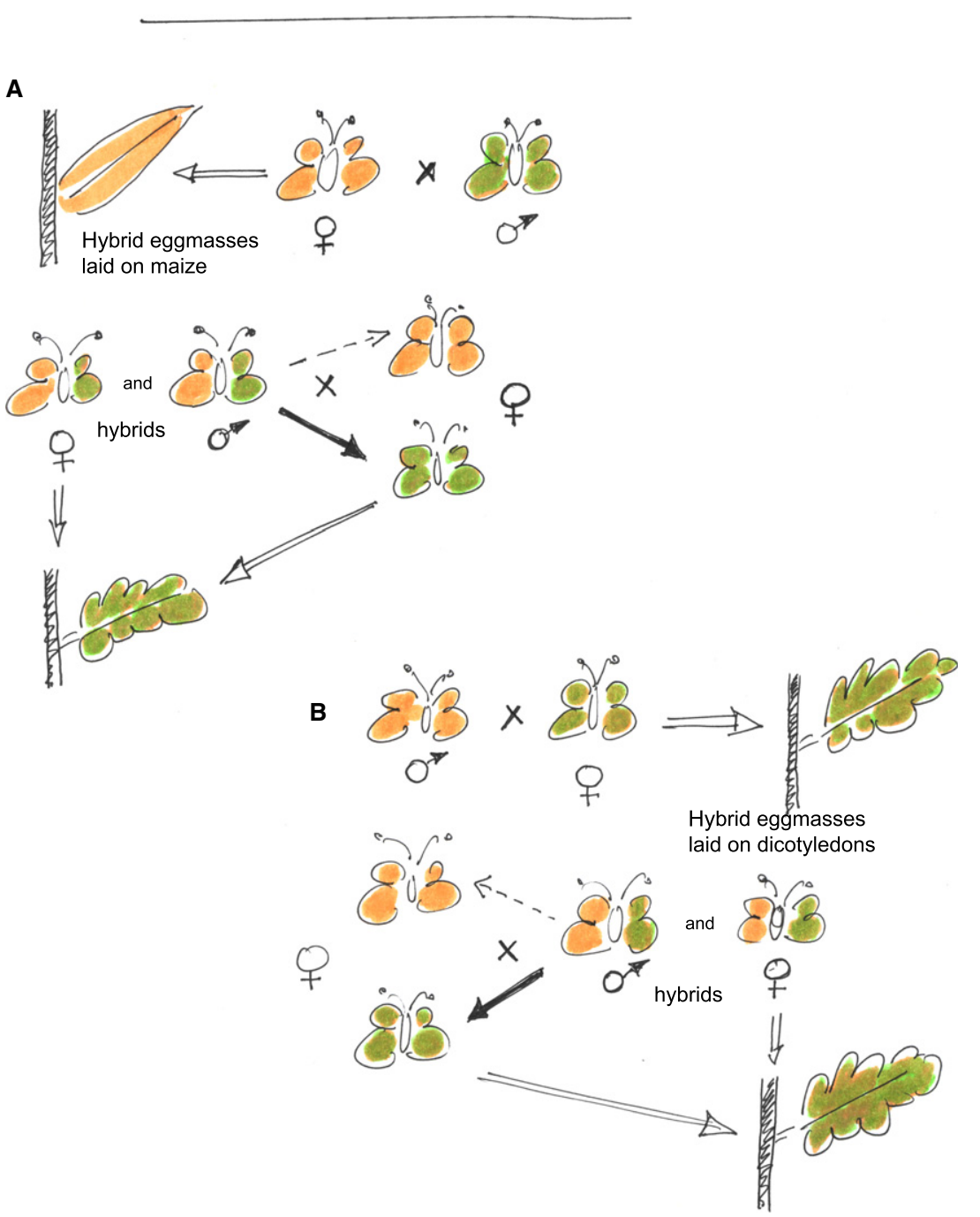

\section{Dominance}

For female oviposition

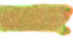

For male attraction to female sex pheromone

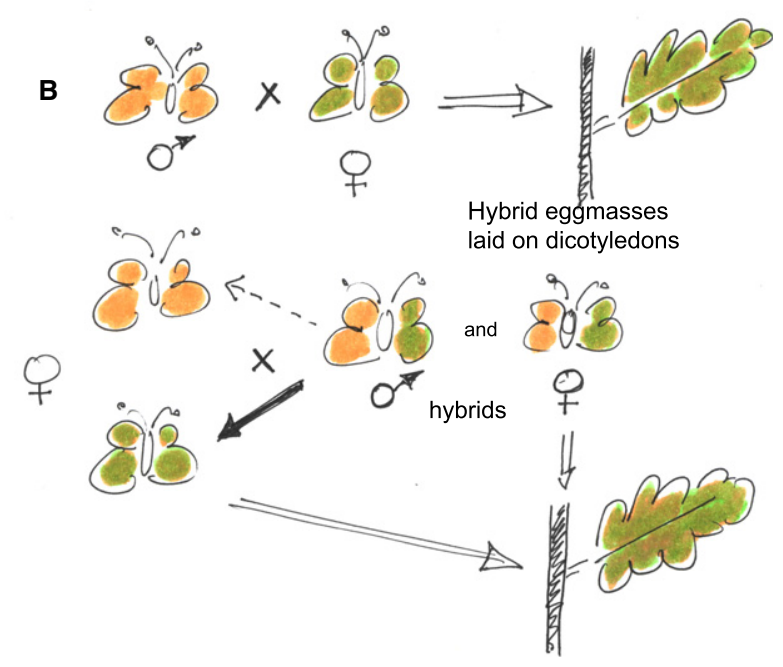

the introduction of maize. The $\mathrm{ACB}$ and $\mathrm{ABB}$ being even more differentiated than the $\mathrm{ECB}$ and $\mathrm{ABB}$, their divergence time - though not formally calculated should be even longer. However, Malausa et al.'s (2007b) estimate must be considered with caution (as mentioned by the authors themselves) because of several possible biases (e.g. the neutral vs. selective nature of the genes sequenced or the parameters of the demographic model used). The estimation method needs to be refined to determine whether divergence time is really incompatible with divergence having occurred mostly after the introduction of maize into Europe and Asia.
Fig. 3 Asymmetric gene flow from $\mathrm{ACB}$ towards $\mathrm{ABB}$. This requires (i) a dominance of the preference for oviposition on dicotyledons over the preference for oviposition on maize (i.e. that hybrid females prefer laying eggs on dicotyledons rather than on maize) and (ii) a dominance of male attraction to the sex pheromone blend emitted by $O$. scapulalis females over attraction to O. furnacalis females (i.e. that hybrid males are more attracted by $O$. scapulalis females than by $O$. furnacalis females). Hence, hybrids emerging from egg masses laid on maize by $O$. furnacalis females mated by O. scapulalis males (A) or on dicotyledons by $O$. scapulalis females mated by $O$. furnacalis males (B) would mate preferentially with $O$. scapulalis females (for hybrid males) and oviposit mostly on dicotyledons (for hybrid females).
Conversely, the ACB and ECB display a number of patterns compatible with an ecological speciation scenario. First, their reproductive isolation from the ABB is incomplete, and there is probably some ongoing gene flow within each pair of taxa. In both cases, sexual isolation seems mostly (if not exclusively) due to premating barriers. However, unlike many other cases of host races/sibling species diverging through ecological speciation, such premating barriers do not seem to be a by-product of ecological adaptation (except possibly temporal isolation: Thomas et al. 2003 but see Malausa et al. 2005). Premating barriers seem to be mostly based on sex pheromones (female ECB: Klun \& Brindley 1970; 
female ACB: Ando et al. 1980; male ECB: Lassance \& Löfstedt 2009), short-range acoustic communication systems (Takanashi et al. 2010 for ECB, Nakano et al. 2006 for $\mathrm{ACB}$ ) and/or other yet unknown short-range signals (Pélozuelo et al. 2007 for ECB, this study for ACB).

Second, ECB larvae have better feeding performance on maize than on all other host plants tested so far (Calcagno et al. 2007), and the ACB shows specific adaptation against chemical defences present in maize (Kojima et al. 2010) and better larval survival and shorter development time on maize than on beans (Goto \& Funayama 1994), although both species are able to complete their life cycle in several other host plants (ECB: Leniaud et al. 2006; ACB: Hattori \& Mutuura 1987; Ishikawa et al. 1999). Also, both the ACB and the ECB show oviposition preference for maize over dicotyledons, whereas the reverse is true for the ABB (Bethenod et al. 2005 and Malausa et al. 2008 for ECB; Alpuerto 1985; Talekar et al. 1991; Goto \& Funayama 1994 and Lu et al. 1996 for ACB). Currently, both ECB and ACB massively infest maize - more than any other host plant (Bontemps et al. 2004 and Leniaud et al. 2006 for ECB and Alpuerto 1985; Talekar et al. 1991 and Lu et al. 1996 for ACB).

Finally, as expected in a scenario of ecological speciation, the level of genetic differentiation seems variable across the genome (Nosil et al. 2009b; Feder et al. 2012). Indeed, in Europe, the genetic differentiation between $\mathrm{ABB}$ and ECB is rather low (Fst $<0.005-0.01)$ for all but one microsatellite loci investigated so far (Malausa et al. 2007; Frolov et al. 2012). One microsatellite locus, OnT2, displayed a differentiation one order of magnitude higher than all the other loci and was pointed as possibly linked to genes involved in host plant adaptation and/or reproductive isolation between the ECB and ABB (Frolov et al. 2012). Interestingly, in the present study, OnT2 appears again as the most differentiated microsatellite locus when comparing $\mathrm{ACB}$ and $\mathrm{ABB}$. In addition, this high level of differentiation is associated, as in the ECB (Frolov et al. 2012), with a low genetic diversity in the ACB at this particular locus. Hence, this locus might not only be linked to one or several gene(s) involved in food plant specialization and/or sexual isolation, but this(these) gene(s) may have played a key role in the speciation of both ECB and ACB.

Another study based on AFLP genotyping in the ECB, ABB and ACB (Alexandre et al. 2013) also identified sets of loci as candidates to be involved in food specialization and/or sexual isolation in the Asian ( $\mathrm{ACB}$ and $\mathrm{ABB}$ ) and the European species pair (ECB and $\mathrm{ABB}$ ). By contrast to locus OnT2, these AFLP loci appeared to be neither identical nor linked in the ECB and the ACB. However, Alexandre et al. (2013) caution that the question whether or not adaptation to maize involves the same loci in the ECB and the ACB remains unsettled, due to methodological limitations.

\section{Perspectives}

Some important parts of the evolutionary histories of ACB and ECB are still missing for one pair of species (e.g. the asymmetry of introgression and the larval fitness of hybrid in the ACB/ABB pair) or for both (e.g. adult hybrid fitness). However, both species pairs are very similar with respect to most of the genetic and ecological characteristics that were studied so far except three: (i) parasitism (Macrocentrus cingulum (Hymenoptera: Braconidae) heavily infests the $\mathrm{ABB}$, but not the ECB in Europe: Pélissié et al. 2010; however, it infests both the ACB and the ABB in China: Pélissié et al. 2012), (ii) difference in sex pheromones (the ECB and the $A B B$ show polymorphism between the same two female pheromone blends: Pélozuelo et al. 2004, 2007; Takanashi et al. 2005; however, the ACB uses a female pheromone that is different from any of these two blends: Ando et al. 1980; ECB and ABB male pheromones consist of varying proportions of four compounds, only two of which seem to be found in the ACB male pheromone: Lassance \& Löfstedt 2009), and (iii) close-range acoustic signalling (no difference was detected between the $\mathrm{ABB}$ and the ECB, but the ACB and the ABB use markedly different signals: Takanashi et al. 2010).

Hence, while natural selection obviously shaped ACB and ECB populations for efficient feeding on maize, the link between this adaptation and reproductive isolation from closely related taxa such as the $A B B$ remains an open question for both pest species. A most intriguing aspect is to understand what may have driven the evolution of strong premating barriers - differences in female and male sex pheromones, short-range mechanisms, courtship ultrasounds - which are unlikely to be involved in host plant adaptation. As neither the ECB and $\mathrm{ABB}$ nor the $\mathrm{ACB}$ and $\mathrm{ABB}$ are fully isolated from each other, the evolution of these premating barriers has to overcome the selection-recombination antagonism (Felsenstein 1981). There is no obvious indication that the premating barriers documented so far between the $\mathrm{ABB}, \mathrm{ECB}$ and $\mathrm{ACB}$ might be due to any 'magic trait' simultaneously ensuring reproductive isolation and adaptation to host plant (Gavrilets 2004). The more likely hypothesis seems to be a tight linkage between genes governing assortative mating and genes ensuring adaptation to host plant, as found in several other cases of ecological speciation (reviewed by Schluter \& Conte 2009). Genomic and functional approaches could contribute to testing such hypothesis in the future. 


\section{Acknowledgements}

We thank Drs. A.N. Frolov, W.Y. Zhou, Y.R. Sheng, L.Y. Ding and H.Y. Ping for their kind help in collecting insects in Khabarovsk, Wuhan, Shenyang, Kunming and Shanghai, respectively, and Dr. T. Takanashi for his help with access to the Japanese literature. We also thank Mr. L.J. Yuan and the Hunan China International Travel Center for their help in arranging travels in China. We finally thank Actions Ponctuelles de Coopération and Congé pour Recherches ou Conversion Thématique of Toulouse University for funding S.P.'s travelling to China in 2005, the Agricultural Academy of Sciences in Beijing for financing S.P.'s stay in 2009, and ANR project BIOCOSMAC (ANR-08-STRA-05-02). The Laboratoire Evolution \& Diversité Biologique is partly supported by project TULIP (ANR-10-LABX-41). Genetic data used in this work were (partly) produced through the technical facilities of the Centre Méditerranéen Environnement Biodiversité.

\section{References}

Alexandre H, Ponsard S, Bourguet D et al. (2013) When history repeats itself: exploring the genetic architecture of host-plant adaptation in two closely related Lepidopteran species. PLoS ONE, 8, e69211.

All China Corn Borer Research Group (1988) Studies on the identification of the dominant corn borer species in China. Acta Phytophylacica Sinica, 15, 145.

Alpuerto VV (1985) Corn Borer (Ostrinia Furnacalis Guénée) (Lepidoptera: Pyraustidae) Damage to Different Varieties of Cotton (Gossypium Hirsutum L.) and its Ovipositional and Feeding Preference. p. 92. University of the Philippines at Los Banos, College, Laguna.

Anderson EC, Thompson EA (2002) A model-based method for identifying species hybrids using multilocus genetic data. Genetics, 160, 1217-1229.

Ando T, Saito O, Arai K, Takahashi N (1980) (Z)- and (E)-12tetradecenyl acetates: sex pheromone components of Oriental corn borer (Lepidoptera: Pyralidae. Agricultural Biological Chemistry, 44, 2643-2649.

Bethenod M-T, Thomas Y, Rousset F et al. (2005) Genetic isolation between two sympatric host plant races of the European corn borer, Ostrinia nubilalis Hübner. II. Assortative mating and host plant preferences for oviposition. Heredity, 94, 264-270.

Bontemps A, Bourguet D, Pélozuelo L, Bethenod M-T, Ponsard $S$ (2004) Managing the evolution of $B t$ resistance in natural populations of the European corn borer, Ostrinia nubilalis: host plant, host race and pherotype of adult males in aggregation sites. Proceedings of the Royal Society of London B, 271, 2179-2185.

Bourguet D, Bethenod M-T, Trouvé C, Viard F (2000) Hostplant diversity of the European corn borer Ostrinia nubilalis: what value for sustainable transgenic insecticidal $B t$ maize? Proceedings of the Royal Society of London B: Biological Sciences, 267, 1177-1184.

Calcagno V, Thomas Y, Bourguet D (2007) Sympatric host races of the European corn borer: adaptation to host plants and hybrid performance. Journal of Evolutionary Biology, 20, 1720-1729.

Carroll SP, Loye JE, Dingle H, Mathieson M, Famula TR, Zalucki MP (2005) And the beak shall inherit-evolution in response to invasion. Ecology Letters, 8, 944-951.
Chapuis M, Estoup A (2007) Microsatellite null alleles and estimation of population differentiation. Molecular and Biological Evolution, 24, 621-631.

Coates BS, Sumerford DV, Hellmich RL, Lewis LC (2005) Partial mitochondrial genome sequences of Ostrinia nubilalis and Ostrinia furnacalis. International Journal of Biological Science, 1, 13-18.

Dalecky A, Bogdanowicz SM, Dopman EB, Bourguet D, Harrison RG (2006) Two multiplex sets of eight and five microsatellite markers for the European corn borer, Ostrinia nubilalis Hübner (Lepidoptera: Crambidae). Molecular Ecology Notes, 6, 945-947.

Domingue MJ, Musto CJ, Linn CE Jr, Roelofs WL, Baker TC (2008) Olfactory neuron responsiveness and pheromone blend preference in hybrids between Ostrinia furnacalis and Ostrinia nubilalis (Lepidoptera: Crambidae). Journal of Insect Physiology, 54, 1261-1270.

Drès M, Mallet J (2002) Host races in plant-feeding insects and their importance in sympatric speciation. Philosophical Transaction of the Royal Society of London B: Biological Sciences, 357, $471-492$.

Elias M, Faria R, Gompert Z, Hendry AP (2012) Factors Influencing Progress toward Ecological Speciation. International Journal of Ecology, 2012, Article ID 235010.

Evanno G, Regnaut S, Goudet J (2005) Detecting the number of clusters of individuals using the software structure: a simulation study. Molecular Ecology, 14, 2611-2620.

Feder JL, Berlocher SH, Roethele JB et al. (2003) Allopatric genetic origins for sympatric host-plant shifts and race formation in Rhagoletis. Proceedings of the National Academy of Sciences of the USA, 100, 10314-10319.

Feder JL, Egan SP, Nosil P (2012) The genomics of speciationwith-gene-flow. Trends in Genetics, 28, 342-350.

Felsenstein J (1981) Skepticism towards Santa Rosalia, or why are there so few kinds of animals? Evolution, 35, 124-138.

Fontaine MC, Baird SJE, Piry S et al. (2007) Rise of oceanographic barriers in continuous populations of a cetacean: the genetic structure of harbour porpoises in Old World waters. BMC Biology, 5, 30.

Frolov AN (1984) Biotaxonomic analysis of harmful species of the genus Ostrinia Hbn. Ethologiya Nasekomykh, Trudy Vsesoyuznogo Entomologitsheskogo Obshchestva, VI, 4-100. (In Russian).

Frolov AN, Bourguet D, Ponsard S (2007) Reconsidering the taxonomy of several Ostrinia species in the light of reproductive isolation: a tale for E. Mayr. Biological Journal of the Linnean Society, 91, 49-72.

Frolov AN, Audiot P, Bourguet D et al. (2012) From Russia with lobe: genetic differentiation in trilobed uncus Ostrinia spp. follows food plant, not hairy legs. Heredity, 108, 147-156.

Gavrilets S (2004) Fitness Landscapes and the Origin of Species. Princeton University Press, Princeton.

Gay JP (1999) Maïs. Atlantica, Biarritz. (In French).

Goto M, Funayama S (1994) Larval development and host preference of Ostrinia furnacalis and O. scapulalis in corn and bean. Journal of the Yamagata Agriculture and Forestry Society, 51, 63-67.

Goudet J (1999) FSTAT, a program to estimate and test gene diversities and fixation indices (version 2.8). Updated from Goudet J (1995). FSTAT (vers. 1.2): a computer program to calculate F-statistics. Journal of Heredity, 86, 485-486. 
Hattori I, Mutuura A (1987) Identification of Japanese species belonging to the genus Ostrinia with the host relationships. Plant Protection (Shokubutsu Boeki), 41, 62-69. (In Japanese).

Hendry AP (2009) Ecological speciation! Or the lack thereof? Canadian Journal of Fish and Aquatic Science, 66, 1383-1398.

Huang Y, Tatsuki S, Kim CG et al. (1997) Identification of sex pheromone of Adzuki bean borer, Ostrinia scapulalis. Journal of Chemical Ecology, 23, 2791-2802.

Hubisz MJ, Falush D, Stephens M, Pritchard JK (2009) Inferring weak population structure with the assistance of sample group information. Molecular Ecology Resources, 9, 1322-1332.

Ishikawa Y, Takanashi T, Kim CG, Hoshizaki S, Tatsuki S, Huang Y (1999) Ostrinia spp. in Japan: their host plants and sex pheromones. Entomologia Experimentalis et Applicata, 91, 237-244.

Jakobsson M, Rosenberg NA (2007) CLUMPP: a cluster matching and permutation program for dealing with label switching and multimodality in analysis of population structure. Bioinformatics, 23, 1801-1806.

Kim CG, Hoshizaki S, Huang YP, Tatsuki S, Ishikawa Y (1999) Usefulness of mitochondrial COII gene sequences in examining phylogenetic relationships in the Asian corn borer, Ostrinia furnacalis, and allied species (Lepidoptera: Pyralidae). Applied Entomology and Zoology, 34, 405-412.

Kim KS, Coates BS, Hellmich RL, Sumerford DV, Sappington TW (2008) Isolation and characterization of microsatellite loci from the European corn borer, Ostrinia nubilalis (Hübner) (Insecta: Lepidoptera: Crambidae). Molecular Ecology Resources, 8, 409-411.

Klun JA, Brindley TA (1970) Cis-11-Tetradecenyl acetate, a sex stimulant of the European corn borer. Journal of Economic Entomology, 63, 779-780.

Kojima W, Fujii T, Suwa M, Miyazawa M, Ishikawa Y (2010) Physiological adaptation of the Asian corn borer Ostrinia furnacalis to chemical defenses of its host plant, maize. Journal of Insect Physiology, 56, 1349-1355.

Lassance JM, Löfstedt C (2009) Concerted evolution of male and female display traits in the European corn borer, Ostrinia nubilalis. BMC Biology, 7, 10.

Leniaud L, Audiot P, Bourguet D et al. (2006) Genetic structure of European and Mediterranean maize borer populations on wild and cultivated host plants. Entomologia Experimentalis et Applicata, 120, 51-62.

Lenormand T (2012) From local adaptation to speciation: specialization and reinforcement. International Journal of Ecology, 2012, Article ID 508458.

Li WH, Gao F (1985) Identification of corn borers and their allied species in China. Plant Protection (Zhiwu Baohu), 9, 14-15. (In Chinese).

Li WD, Chen SX, Qin JG (2003) Identification of sympatric Asian and European corn borers. Entomological Knowledge, 40, 31-35. (In Chinese).

Linn CE Jr, O'Connor M, Roelofs WL (2003) Silent genes and rare males: a fresh look at pheromone blend response specificity in the European corn borer moth, Ostrinia nubilalis. Journal of Insect Science, 3, 15.

Linn CE Jr, Musto CJ, Roelofs WL (2007) More rare males in Ostrinia: response of Asian corn borer to the sex pheromone of the European corn borer. Journal of Chemical Ecology, 33, 199-212.
Lu ZX, Yang ZF, Hu C (1996) Effects of host plants on feeding, development and reproduction of Asian corn borer. Acta Phytophylacica Sinica, 23, 126-130. (In Chinese).

Malausa T, Bethenod M-T, Bontemps A, Bourguet D, Cornuet JM, Ponsard S (2005) Assortative mating in sympatric host races of the European corn borer. Science, 308, 258-260.

Malausa T, Dalecky A, Ponsard S et al. (2007a) Genetic structure and gene flow in French populations of two Ostrinia taxa: host races or sibling species? Molecular Ecology, 16, 4210-4222.

Malausa T, Leniaud L, Martin JF et al. (2007b) Molecular differentiation at nuclear loci in French host races of the European corn borer (Ostrinia nubilalis). Genetics, 176, 2343-2355.

Malausa T, Pélissié B, Piveteau V, Pélissier C, Bourguet D, Ponsard S (2008) Differences in oviposition behaviour of two sympatric sibling species of the Ostrinia genus. Bulletin of Entomological Research, 98, 193-201.

Martel C, Réjasse A, Rousset F, Bethenod MT, Bourguet D (2003) Host-plant-associated genetic differentiation in northern French populations of the European corn borer. Heredity, 90, 141-149.

Matsubayashi KW, Ohshima I, Nosil P (2010) Ecological speciation in phytophagous insects. Entomologia Experimentalis et Applicata, 134, 1-27.

Mutuura A, Munroe E (1970) Taxonomy and distribution of the European corn borer and allied species: genus Ostrinia (Lepidoptera: Pyralidae). Memoirs of the Entomological Society of America, 71, 1-112.

Nakano R, Ishikawa Y, Tatsuki S, Surlykke A, Skals A, Takanashi $\mathrm{T}$ (2006) Ultrasonic courtship song in the Asian corn borer moth, Ostrinia furnacalis. Naturwissenschaften, 93, 292-296.

Nosil P, Harmon LJ, Seehausen O (2009a) Ecological explanations for (incomplete) speciation. Trends in Ecology and Evolution, 24, 145-156.

Nosil P, Funk DJ, Ortiz-Barrientos D (2009b) Divergent selection and heterogeneous genomic divergence. Molecular Ecology, 18, 375-402.

van Oosterhout C, Hutchinson WF, Wills DPM, Shipley P (2004) MICRO-CHECKER: software for identifying and correcting genotyping errors in microsatellite data. Molecular Ecology Notes, 4, 535-538.

Peccoud J, Simon JC (2010) The pea aphid complex as a model of ecological speciation. Ecological Entomology, 35, 119-130.

Pélissié B, Ponsard S, Tokarev YS et al. (2010) Did the introduction of maize into Europe provide enemy-free space to O. nubilalis? - parasitism differences between two sibling species of the genus Ostrinia. Journal of Evolutionary Biology, 23, 350-361.

Pélissié B, Ponsard S, Kergoat GJ, Bourguet D (2012) Phylogeny and population genetics of the Asian and European parasitoid Macrocentrus cingulum using mitochondrial and nuclear loci. Entomologia Experimentalis et Applicata, 145, 1-14.

Pélozuelo L, Malosse C, Genestier G, Guenego H, Frérot B (2004) Host-plant specialization in pheromone strains of the European corn borer Ostrinia nubilalis in France. Journal of Chemical Ecology, 30, 335-351.

Pélozuelo L, Meusnier S, Audiot P, Bourguet D, Ponsard S (2007) Sex pheromones are for meeting not for mating. PLoS ONE, 2, e555.

Ponsard S, Bethenod MT, Bontemps A, Pélozuelo L, Souqual MC, Bourguet D (2004) Carbon stable isotopes: a tool for 
studying the mating, oviposition, and spatial distribution of races of European corn borer, Ostrinia nubilalis, among host plants in the field. Canadian Journal of Zoology, 82, 1177-1185.

Pritchard JK, Stephens M, Donnelly P (2000) Inference of population structure using multilocus genotype data. Genetics, 155, 945-959.

Roelofs WL, Liu WT, Hao GX, Jiao H, Rooney AP, Linn CE (2002) Evolution of moth sex pheromones via ancestral genes. Proceedings of the National Academy of Science USA, 99, 13621-13626.

Rosenblum EB, Harmon LJ (2011) "Same same but different": replicated ecological speciation at white sands. Evolution, 65, 946-960.

Rousset F (1997) Genetic differentiation and estimation of gene flow from $F$-statistics under isolation by distance. Genetics, 145, 1219-1228.

Rousset F (2008) genepop'007: a complete re-implementation of the genepop software for Windows and Linux. Molecular Ecology Resources, 8, 103-106.

Rundle H, Nosil P (2005) Ecological speciation. Ecology Letters, 8, 336-352.

Sambrook J, Fritsch E, Maniatis T (1989) Molecular Cloning: A Laboratory Manual. Cold Spring Harbor Laboratory Press, New York.

Schluter D (2001) Ecology and the origin of species. Trends in Ecology and Evolution, 16, 372-380.

Schluter D (2009) Evidence for ecological speciation and its alternative. Science, 323, 737-741.

Schluter D, Conte GL (2009) Genetics and ecological speciation. Proceedings of the National Academy of Science USA, 106, 9955-9962.

Schluter D, Nagel LM (1995) Parallel speciation by natural selection. The American Naturalist, 146, 292-301.

Takanashi T, Huang Y, Takahasi KRYO, Hoshizaki S, Tatsuki S, Ishikawa Y (2005) Genetic analysis and population survey of sex pheromone variation in adzuki bean borer moth, Ostrinia scapulalis. Biological Journal of the Linnean Society, 84, 143-160.

Takanashi T, Nakano R, Surlykke A et al. (2010) Variation in courtship ultrasounds of three Ostrinia moths with different sex pheromones. PLoS ONE, 5, e13144.

Talekar NS, Lin CP, Yin YF, Ling MY, Wang YD, Chang DCY (1991) Characteristics of infestation by Ostrinia furnacalis (Lepidoptera: Pyralidae) in mungbean. Journal of Economic Entomology, 84, 1499-1502.

Thomas Y, Bethenod MT, Pélozuelo L, Frérot B, Bourguet D (2003) Genetics isolation between two sympatric host-plant races of the European corn borer, Ostrinia nubilalis Hübner. I. Sex pheromone, moth emergence timing, and parasitism. Evolution, 57, 261-273.

Vähä JP, Primmer CR (2006) Efficiency of model-based Bayesian methods for detecting hybrid individuals under different hybridization scenarios and with different numbers of loci. Molecular Ecology, 15, 63-72.

Wang RJ, Yan FM, Li SG, Li SW (1995) Allozyme differentiation among nine populations of the corn borer (Ostrinia) in China. Biochemical Genetics, 33, 413-420.
Weir BS, Cockerham CC (1984) Estimating F-Statistics for the analysis of population structure. Evolution, 38, 1358-1370.

Xu M, Sun S, Wang R, Li S (1998) Genetic variation and phylogenetic relationships among six populations of corn borers in China. Biochemical Genetics, 36, 289-297.

D.B., S.P., L.J. and Z.Y.W. were all involved in field sampling. S.M. reared the strains and performed all crosses and backcrosses in laboratory conditions. P.A. did all the genotyping. D.B., S.P. and R.S. analysed the data. All authors but S.M. contributed to the writing of the article and have checked and approved the final version of the article.

\section{Data accessibility}

The molecular data set (microsatellite and COI genotypes) has been deposited in Dryad (doi:10.5061/dryad. $\mathrm{k} 5 \mathrm{c} 8 \mathrm{v})$.

\section{Supporting information}

Additional supporting information may be found in the online version of this article.

Table S1 Percentage of the various male mid-tibiae in the populations collected on maize and dicotyledons. $\mathrm{N}$ : number of males examined.

Table S2 $P$-values for departure from heterozygosity expected under Hardy-Weinberg equilibrium.

Table S3 Genetic differentiation between ACB populations collected on maize in China and Eastern Russia. Pairwise FST $\{$ ENA $\}$ values are given below the diagonal.

Table S4 Genetic differentiation between ABB populations collected on dicotyledons in China.

Table S5 Genetic differentiation (pairwise FST $\{$ ENA\}) between $\mathrm{ABB}$ populations collected on dicotyledons vs. $\mathrm{ACB}$ collected on maize in China and Eastern Russia.

Fig. S1 Bayesian clustering analysis of populations collected on maize and dictotyledons in Europe, Kazakhstan, China and Eastern Russia, for $K=2$ to $K=5$.

Fig. S2 Relation between genetic differentiation and geographical distance between Ostrinia populations collected on maize - excluding the population collected at Yining - or on dicotyledons. 